\title{
Conjunctival sac bacterial culture of patients using levofloxacin eye drops before cataract surgery: A real-world, retrospective study
}

\author{
Zhenyu Wang \\ Peking University Third Hospital \\ Pei Zhang \\ Peking University Third Hospital \\ Chen Huang \\ Peking University Third Hospital \\ Yining Guo \\ Peking University Third Hospital \\ Xuhe Dong \\ Peking University Third Hospital \\ Xuemin Li ( $\nabla 13911254862 @ 163 . c o m$ ) \\ Peking University Third Hospital
}

\section{Research article}

Keywords: Real world study, antibiotic prophylactic therapy, clinical factor, levofloxacin

Posted Date: June 14th, 2021

DOI: https://doi.org/10.21203/rs.3.rs-611272/v1

License: (c) (i) This work is licensed under a Creative Commons Attribution 4.0 International License. Read Full License 


\section{Abstract \\ Purpose}

To reveal the association between clinical factors and conjunctival sac bacterial load and offer prophylaxis suggestions.

\section{Methods}

We retrieved real-world data (RWD) of patients using levofloxacin preoperatively. Retrieved data included information on the conjunctival sac bacterial culture, gender, presence of hypertension and diabetes mellitus (DM), and history of hospital-based surgeries. Data was analyzed using SPSS 24.0.

\section{Results}

RWD of 15,415 cases (patients) were retrieved. Among these patients, 5,866 (38.1\%) were males and 9,549 (61.9\%) females. 5,960 (38.7\%) patients had a history of hypertension, and 3,493 (22.7\%) patients had a history of DM. 7,555 (49.0\%) patients had a history of hospital-based operations. There were 274 (1.8\%) positive bacterial cultures. Male patients with hypertension and DM may be at increased risk of having positive bacterial cultures $(P<0.05)$. Staphylococcus epidermidis $(n=56,20.4 \%)$, Kocuria rosea $(n=37,13.5 \%)$, and Micrococcus luteus $(n=32,11.7 \%)$ were the top 3 isolated strains. Most bacterial strains were resistant to various antibiotics except rifampin, and $82.5 \%$ (33 of 40 isolates) of Staphylococcus epidermidis isolates had multidrug antibiotic resistance. Numbers of culture-positive Staphylococcus epidermidis isolates in the male group and non-DM group were greater than those in the female and DM groups, respectively. Micrococcus luteus $(n=11,8.8 \%)$ was found less frequently in non-hypertension group than in hypertension group.

\section{Conclusion}

Gender and the presence of hypertension and DM are risk factors for greater conjunctival sac bacterial loads. We offer a prophylactic suggestion based on the combined use of levofloxacin and rifampin. However, this approach may aggravate risk of multidrug resistance.

\section{Key Messages}

1. Levofloxacin has well-established efficacy and tolerability in the treatment of external ocular infections. However, resistance to levofloxacin has been confirmed in several studies. The species and characteristics of levofloxacin-resistant bacteria in human conjunctival sac have not been systematically summarized.

2. We found that Staphylococcus epidermidis, Kocuria rosea, and Micrococcus luteus were the three most frequently isolated strains in patients who used topical levofloxacin preoperatively.

3. Gender (Male) and the presence of hypertension and DM are risk factors for greater conjunctival sac bacterial loads.

4. We offer a prophylactic suggestion based on the combined use of levofloxacin and rifampin. However, this approach may aggravate the multidrug resistance risk.

\section{Introduction}

Commensal bacterial flora in the conjunctival sac is a potential risk factor for infection after intraocular surgeries [1; 2]. A broad range of commensal bacteria have been identified at the ocular surface of patients with infectious eye disease and have been reported to contribute to the occurrence of endophthalmitis after cataract surgery [2-4]. According to the study of Marlene L. Durand et al [5], Coagulase-negative Staphylococci (70\% of cases), Staphylococcus aureus (10\%), and Streptococcus spp. (9\%) are the major pathogens responsible for endophthalmitis cases after cataract surgery. Without effective preoperative examination and prevention, the bacteria mentioned above may lead to endophthalmitis, a devastating eye infection which can cause irreversible blindness in the infected eye within hours or days of symptom onset [5].

The use of antibiotics is an effective strategy to significantly decrease the incidence of bacterial infections (positive swabs). Deepthi et al. have detected several species of bacteria in the conjunctival sac using culture methods and PCR[6]. According to their study, among 201 isolates, the most often detected genera were Corynebacterium spp. $(n=30,14.93 \%)$, Staphylococcus spp. $(n=26,12.94 \%)$, and Cutibacterium spp. $(n=23,11.44 \%)$, followed by Escherichia spp. $(n=13,6.47 \%)$ and Acinetobacter spp. $(n=12,5.97 \%)$. Most of these species are sensitive to quinolones and fluoroquinolones[7-13]. However, with the widespread use of antibiotics, the resistance rate of bacteria towards antibiotics has gradually increased. The widespread emergence of antibiotic-resistant pathogens has become a severe threat to public health. This problem becomes even worse with a concomitant decline in the development of novel antibiotics and the emergence of multidrug-resistant strains [14; 15]. Moreover, patient-related risk factors such as older age, gender (male), the presence of hypertension and/or diabetes mellitus (DM), and a history of hospital-based surgery may be associated with increasing bacterial load and the emergence of multidrugresistant bacteria [1].

Levofloxacin belongs to fluoroquinolones, which have well-established efficacy and tolerability in the treatment of external ocular infections caused by both Gram-positive and Gram-negative bacteria [16]. It has been proven that topical levofloxacin is well tolerated with rare systemic or ocular adverse events [16]. 
However, resistance to levofloxacin has been confirmed in several studies [17-21]. The species and characteristics of levofloxacin-resistant bacteria in human conjunctival sac have not been systematically summarized.

According to The Food and Drug Administration (FDA), real-world data (RWD) is defined as all data relating to patient health status and/or the delivery of health care, routinely collected from a variety of sources. Moreover, real-world evidence (RWE) is the clinical evidence regarding the usage and potential benefits or risks of a medical product, derived from the analysis of RWD [22]. By studying RWE, clinicians can optimize currently available therapies or develop new prophylactic strategies [23]. It provides support for us to further study the characteristics of levofloxacin resistant bacteria in conjunctival sac.

In the current study, we searched the related literature and reviewed the results of conjunctival sac bacterial cultures of patients that had used Cravit (levofloxacin eye drops, Santen Pharmaceutical Co., Ltd) for antibiotic prophylactic therapy before cataract surgery. With the exception of data from the literature, all RWD were collected in Peking University Third Hospital from 2016 to 2019. By calculating the positive rate, analyzing positive strains and their drug sensitivity, as well as classifying results by clinical factors that may affect the positive rate of cultures, we revealed the association between different clinical factors and the conjunctival sac bacterial load. Further, by analyzing the results we confirmed the necessity for antibiotic use before cataract surgeries and offered prophylaxis suggestions and references.

\section{Methods}

2.1. Ethical approval and consent to participate

All participants provided informed consent, consistent with the tenets of the Declaration of Helsinki. Peking University Third Hospital Medical Ethics Committee approved all procedures carried out in this study (approval number: M2019432).

\subsection{Data screening and selection}

We included all medical records and related literature data and obtained RWD including basic patient information and conjunctival sac bacterial culture information of patients that had used Cravit (levofloxacin eye drops $5 \mathrm{~mL}: 24.4 \mathrm{mg}$, Santen Pharmaceutical Co., Ltd) for antibiotic prophylactic therapy before cataract surgeries. Literature on prophylactic therapy using other antibiotics or povidone-iodine (PVI) was also reviewed and summarized for comparison. For medical records, we restricted the inclusion criteria to patients with cataracts that had visited Peking University Third Hospital from 2016 to 2019 . For published literature, the keywords used were "antibiotics", "prophylactic therapy", and "cataract surgery". We restricted the inclusion criteria to observational cohort studies only. The timing of publication was restricted to the last 10 years (2009-2019). Any study published prior to the last 10 years was considered as outdated and was excluded. Moreover, studies that lacked information regarding age, gender, and previous medical history of patients and were not focused on the conjunctival sac bacterial culture of patients undergoing antibiotic prophylactic therapy were excluded. Publications were also excluded if the concentration of levofloxacin used was different from that in the current study. All relevant literature not included were summarized and compared with our study on the clinical effects of antibiotics and bacterial resistance to them.

\subsection{Data extraction}

After screening medical records and publications, we extracted detailed data including the preoperative conjunctival sac bacterial culture of patients using Cravit, patient gender, presence of hypertension and/or DM, and history of hospital-based surgeries. All conjunctival sac bacterial culture samples were only collected and isolated from patients who had come for cataract surgery and had used Cravit preoperatively, 4 times a day for 3 days, from 2016 to 2019 . For patients who underwent bilateral operations, we only conducted the cataract surgery on one eye at a time. The interval between the left eye operation and right eye operation of each patient was more than one month. The medical records of the first-eye surgeries were retrieved. Patients were asked to only use topical antibiotics on the eyes that were to be operated. The isolates were all collected from the conjunctival sac of patients just before the operation and were identified using the Vitek-2 automated systems (bioMerieux, France). Antimicrobial susceptibility testing (AST) for tobramycin, ceftriaxone, erythromycin, vancomycin, leveofloxacin, ofloxacin, and rifampin was performed using the Kirby-Bauer (K-B) disk diffusion method according to the Clinical and Laboratory Standards Institute (CLSI) guideline.

\subsection{Data analysis}

Data of patient basic information, results of conjunctival sac bacterial culture, and antimicrobial susceptibility testing were collected and recorded using Excel (Microsoft Office 2019; Microsoft Corporation, Redmond, WA, USA). All statistical analyses were conducted using SPSS 24.0 (International Business Machines Corp.). Considering the data frame, distribution and sample sizes of our results, multiple statistical approaches were applied in our studies. Comparison of the incidence of each clinical factor between culture-positive groups and culture-negative groups was performed using the chi-square test. Binary logistic regression analysis was also used to explore the association between clinical factors and the positive culture of conjunctival sac bacteria. The Kruskal-Wallis $\mathrm{H}$ test was conducted to analyze the results of $\mathrm{K}-\mathrm{B}$ test. Due to the small sample sizes for some strains, the Kruskal-Wallis $\mathrm{H}$ test was only conducted on strains of 6 or more isolated samples with K-B test results. Culture-positive patients were divided into two groups according to the clinical factors that were associated with culture results. The presence of various bacteria and their AST results were compared using the chi-square test and Mann-Whitney U test. It was notable that since we involved multiple factors without clear pre-defined hypothesis, multiple testing correction were considered into the final $P$ value threshold $(P<0.001)$. Statistical significance of other tests was defined as $P<0.05$.

\section{Results}

\subsection{Overall results}




\subsubsection{Patients and clinical factors}

RWD of 15,415 cases, including conjunctival sac bacterial cultures, were retrieved. Because the concentration of levofloxacin used in the published literature was different from that in the medical records of our study, and there was a lack of information regarding age, gender, and previous medical history of patients, all RWD were retrieved from the medical records of patients from Peking University Third Hospital. Clinical factors that may affect conjunctival sac bacterial load of patients before cataract surgery are shown in Table 1. Among the total cases, there were 5,866 (38.1\%) males and 9,549 (61.9\%) females. There were 5,960 (38.7\%) patients with a history of hypertension and $3,493(22.7 \%)$ patients with a history of DM. The number of patients with a history of one or more hospital-based operations was 7,555 (49.0\%). There were $169(1.1 \%)$ patients who had undergone bilateral operations and only the medical records of the first-eye surgeries were retrieved.

Table 1

Clinical factors related to conjunctival sac bacterial load in patients before cataract surgery

\begin{tabular}{|c|c|c|c|c|}
\hline & \multicolumn{2}{|c|}{ Conjunctival sac bacterial culture } & \multirow{2}{*}{$x^{2}$} & \multirow[t]{2}{*}{ P-value } \\
\hline & Positive $(n=274)$ & Negative $(n=15141)$ & & \\
\hline Gender & & & 16.888 & $<0.001^{*}$ \\
\hline Male & $137(50.0 \%)$ & $5729(37.8 \%)$ & & \\
\hline Female & $137(50.0 \%)$ & $9412(62.2 \%)$ & & \\
\hline Hypertension & & & 29.054 & $<0.001^{*}$ \\
\hline Yes & $149(54.4 \%)$ & $5811(38.4 \%)$ & & \\
\hline No & $125(45.6 \%)$ & $9330(61.6 \%)$ & & \\
\hline Diabetes mellitus & & & 14.236 & $<0.001^{*}$ \\
\hline Yes & $88(32.1 \%)$ & $3405(22.5 \%)$ & & \\
\hline No & $186(67.9 \%)$ & $11736(77.5 \%)$ & & \\
\hline History of hospital-based surgeries & & & 0.161 & 0.688 \\
\hline Yes & $131(47.8 \%)$ & $7424(49.0 \%)$ & & \\
\hline No & $143(52.2 \%)$ & $7717(51.0 \%)$ & & \\
\hline Notes: ${ }^{a} \star P<0.05$ in two-side $\chi^{2}$ test & & & & \\
\hline${ }^{b} \mathrm{n}$ : number of patients & & & & \\
\hline
\end{tabular}

There were $274(1.8 \%)$ culture samples that were positive, suggesting that these patients had a greater conjunctival sac bacterial load. The positive rate was $1.8 \%$. Male patients $(n=137,2.3 \%)$ and patients with a history of hypertension $(n=149,2.5 \%)$ or DM $(n=88,2.5 \%)$ were at an increased risk of having positive bacterial cultures $(P<0.05)$, but the history of hospital-based surgeries may have had no influence $(P>0.05)$. Besides, the results of binary logistic regression analysis was shown in Table 2 and the logistic model was statistically significant $\left(\chi^{2}(4)=52.686, P<0.001\right)$. Among the 4 independent variables included in the model, gender, presence of hypertension and DM were statistically significant $(P<0.05)$. The risk of positive culture of conjunctival sac bacteria in male was 1.677 times higher than that in female. The risk in patients with hypertension was 1.844 times higher than that in patients without hypertension. The risk in diabetic patients was 1.385 times higher than that in non-diabetic patients. There were only three patients who had undergone bilateral operations, and the interval between the left eye operation and right eye operation of each patient, as previously stated, was more than one month (Table 3).

Table 2

Binary logistic regression analysis of positive conjunctival sac bacterial culture in patients before cataract surgery based on clinical factors

\begin{tabular}{|c|c|c|c|c|c|c|c|c|}
\hline & \multirow[t]{2}{*}{ B } & \multirow[t]{2}{*}{ SE } & \multirow[t]{2}{*}{ Wald } & \multirow[t]{2}{*}{$\mathrm{d} f$} & \multirow[t]{2}{*}{$p$} & \multirow[t]{2}{*}{ Odds Ratio } & \multicolumn{2}{|c|}{$95 \% \mathrm{Cl}$ for Odds Ratio } \\
\hline & & & & & & & Lower & Upper \\
\hline Gender & 0.517 & 0.122 & 17.849 & 1 & $<0.001^{*}$ & 1.677 & 1.319 & 2.131 \\
\hline Hypertension & 0.612 & 0.127 & 23.378 & 1 & $<0.001^{*}$ & 1.844 & 1.439 & 2.364 \\
\hline Diabetes mellitus & 0.326 & 0.135 & 5.825 & 1 & $0.016^{*}$ & 1.385 & 1.063 & 1.805 \\
\hline History of hospital-based surgeries & -0.125 & 0.123 & 1.029 & 1 & 0.31 & 0.883 & 0.694 & 1.123 \\
\hline Constant & -4.55 & 0.124 & 1344.781 & 1 & $<0.001^{\star}$ & 0.011 & & \\
\hline \multicolumn{9}{|c|}{ Notes: a ${ }^{\star} P<0.05$ in binary logistic regression analysis } \\
\hline
\end{tabular}


Table 3

Summary of conjunctival sac bacteria of the patients who had undergone bilateral operations

\begin{tabular}{|c|c|c|c|c|c|c|c|c|c|c|c|}
\hline \multirow{2}{*}{$\begin{array}{l}\text { Patient } \\
\text { No. }\end{array}$} & \multirow[t]{2}{*}{ Gender } & \multirow{2}{*}{$\begin{array}{l}\text { Age } \\
\text { (y) }\end{array}$} & & \multirow{2}{*}{$\begin{array}{l}\text { Operation } \\
\text { date }\end{array}$} & \multirow{2}{*}{$\begin{array}{l}\text { Isolated } \\
\text { bacteria }\end{array}$} & \multicolumn{6}{|c|}{ Zoom diameter of K-B test of antimicrobial agent $(\mathrm{mm})$} \\
\hline & & & $\begin{array}{l}\text { Left/Right } \\
\text { Eye }\end{array}$ & & & Tobramycin & Ceftriaxone & Erythromycin & Vancomycin & Levofloxacin & Of \\
\hline \multirow[t]{2}{*}{1} & Male & 67 & OD & $2018 / 9 / 10$ & $\begin{array}{l}\text { Micrococcus } \\
\text { luteus }\end{array}$ & - & 34 & 12 & 23 & 22 & 20 \\
\hline & & & os & $2018 / 10 / 11$ & $\begin{array}{l}\text { Unidentifiable } \\
\text { bacteria }\end{array}$ & 16 & 28 & 10 & 30 & 30 & 24 \\
\hline \multirow[t]{2}{*}{2} & Female & 75 & OD & $2017 / 6 / 7$ & $\begin{array}{l}\text { Acinetobacter } \\
\text { Iwoffii }\end{array}$ & 10 & 10 & 7 & 8 & 14 & 12 \\
\hline & & & os & $2018 / 5 / 24$ & $\begin{array}{l}\text { Unidentifiable } \\
\text { bacteria }\end{array}$ & 10 & 24 & - & 14 & 9 & 9 \\
\hline \multirow[t]{2}{*}{3} & Female & 72 & OD & $2017 / 12 / 7$ & $\begin{array}{l}\text { Inactive } \\
\text { biochemical } \\
\text { spectrum }\end{array}$ & - & 16 & 16 & 20 & 7 & 7 \\
\hline & & & os & $2018 / 1 / 14$ & $\begin{array}{l}\text { Kocuria } \\
\text { kristinae }\end{array}$ & - & 28 & 17 & 22 & - & - \\
\hline
\end{tabular}

\subsubsection{Culture identification}

Of all the 274 positive culture samples, Staphylococcus epidermidis $(n=56,20.4 \%)$, Kocuria rosea $(n=37,13.5 \%)$, and Micrococcus luteus $(n=32,11.7 \%)$ were the three most frequently isolated strains, accounting for $45.6 \%$ of culture-confirmed cases. The top 10 species of culture-positive samples and their amounts are shown in the Fig. 1.

\subsubsection{Antimicrobial susceptibility testing}

Among the 274 culture-positive samples, information on antimicrobial susceptibility testing using the K-B test was recorded for 234 ( $85.4 \%$ ) samples and is summarized in Table 4. For Staphylococcus epidermidis, Kocuria rosea, Kocuria kristinae, Kocuria varians, Micrococcus luteus, Micrococcus lylae, Moraxella spp., Brevundimonas diminuta, inactive biochemical spectra, and unidentifiable bacterial groups, there were statistically significant differences in resistance to different antimicrobial agents $(P<0.05)$. The zone diameters of rifampin in the K-B test were the largest, which means all these bacteria were most sensitive to rifampin. 
Table 4

Number of isolated bacteria and K-B test results

\begin{tabular}{|c|c|c|c|c|c|c|c|c|c|c|}
\hline \multirow[t]{2}{*}{ Isolated bacteria } & \multirow[t]{2}{*}{$n(\%)$} & \multirow{2}{*}{$\begin{array}{l}\text { Number } \\
\text { of K-B } \\
\text { test } \\
\text { results }\end{array}$} & \multicolumn{7}{|c|}{ Zone Diameter of Antimicrobial agent (mm) } & \multirow[t]{2}{*}{$P$} \\
\hline & & & Tobramycin & Ceftriaxone & Erythromycin & Vancomycin & Levofloxacin & Ofloxacin & Rifampin & \\
\hline $\begin{array}{l}\text { Staphylococcus } \\
\text { spp. }\end{array}$ & $76(27.7 \%)$ & & & & & & & & & \\
\hline $\begin{array}{l}\text { Staphylococcus } \\
\text { epidermidis }\end{array}$ & $56(20.4 \%)$ & 40 & $7(0)$ & $22.5(19.25)$ & $0(0)$ & $15(14)$ & 10.5(0) & $7(0)$ & $30(28)$ & $\begin{array}{l}< \\
0.0\end{array}$ \\
\hline $\begin{array}{l}\text { Staphylococcus } \\
\text { hominis }\end{array}$ & $7(2.6 \%)$ & 2 & $7(0)$ & $23.5(23)$ & $8.5(7)$ & 19.5(19) & $21(12)$ & $20.5(12)$ & $35(34)$ & - \\
\hline $\begin{array}{l}\text { Staphylococcus } \\
\text { warneri }\end{array}$ & $4(1.5 \%)$ & 3 & $0(0)$ & 20(18) & $24(7)$ & $14(12)$ & 18(15) & $18(11)$ & $24(20)$ & - \\
\hline $\begin{array}{l}\text { Staphylococcus } \\
\text { capitalis }\end{array}$ & $2(0.7 \%)$ & 1 & 13 & 18 & 0 & 17 & 10 & 0 & 30 & - \\
\hline $\begin{array}{l}\text { Staphylococcus } \\
\text { aureus }\end{array}$ & $1(0.4 \%)$ & 0 & & & & & & & & \\
\hline $\begin{array}{l}\text { Staphylococcus } \\
\text { auricularis }\end{array}$ & $1(0.4 \%)$ & 1 & 20 & 22 & 26 & 15 & 22 & 20 & 30 & - \\
\hline $\begin{array}{l}\text { Staphylococcus } \\
\text { caprae }\end{array}$ & $1(0.4 \%)$ & 1 & 20 & 26 & 30 & 12 & 22 & 22 & 28 & - \\
\hline $\begin{array}{l}\text { Staphylococcus } \\
\text { gallinarum }\end{array}$ & $1(0.4 \%)$ & 0 & & & & & & & & \\
\hline $\begin{array}{l}\text { Staphylococcus } \\
\text { haemolyticus }\end{array}$ & $1(0.4 \%)$ & 1 & 12 & 18 & 0 & 15 & 0 & 0 & 28 & - \\
\hline $\begin{array}{l}\text { Staphylococcus } \\
\text { lentus }\end{array}$ & $1(0.4 \%)$ & 1 & 18 & 32 & 20 & 16 & 12 & 12 & 30 & - \\
\hline $\begin{array}{l}\text { Staphylococcus } \\
\text { saprophyticus }\end{array}$ & $1(0.4 \%)$ & 1 & 20 & 22 & 22 & 14 & 20 & 16 & 24 & - \\
\hline Kocuria spp. & $67(24.5 \%)$ & & & & & & & & & \\
\hline Kocuria rosea & $37(13.5 \%)$ & 35 & $20(11)$ & $28(24)$ & $14(8)$ & $21(20)$ & $0(0)$ & $0(0)$ & $30(28)$ & $\begin{array}{l}< \\
0.0\end{array}$ \\
\hline Kocuria kristinae & $19(6.9 \%)$ & 18 & $11(0)$ & $28(23.5)$ & $15(0)$ & $24(18)$ & $20(0)$ & $16.5(0)$ & $30(24.75)$ & $\begin{array}{l}< \\
0.0\end{array}$ \\
\hline Kocuria varians & $11(4.0 \%)$ & 10 & $21(17.5)$ & $22(17.5)$ & $15.5(0)$ & $24(20)$ & $15(10.25)$ & 18(11.5) & $33.5(29.5)$ & $\begin{array}{l}< \\
0.0\end{array}$ \\
\hline Micrococcus spp. & $39(14.2 \%)$ & & & & & & & & & \\
\hline $\begin{array}{l}\text { Micrococcus } \\
\text { luteus }\end{array}$ & $32(11.7 \%)$ & 29 & $11(8)$ & $30(27)$ & $12(8)$ & $20(18)$ & $20(16)$ & $18(14)$ & $30(29)$ & 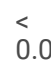 \\
\hline Micrococcus lylae & $7(2.6 \%)$ & 7 & $13(10)$ & $26(20)$ & $10(8)$ & $16(14)$ & $18(14)$ & $14(14)$ & $30(28)$ & $\begin{array}{l}< \\
0.0\end{array}$ \\
\hline Acinetobacter spp. & $12(4.4 \%)$ & & & & & & & & & \\
\hline $\begin{array}{l}\text { Acinetobacter } \\
\text { Iwoffii }\end{array}$ & $9(3.3 \%)$ & 5 & $20(14)$ & $14(5)$ & $8(3.5)$ & $9(8.5)$ & $14(7)$ & 13(11.5) & $20(15.5)$ & - \\
\hline $\begin{array}{l}\text { Acinetobacter } \\
\text { baumannii }\end{array}$ & $1(0.4 \%)$ & 0 & & & & & & & & \\
\hline Acinetobacter junii & $1(0.4 \%)$ & 1 & 11 & 18 & 16 & 10 & 16 & 15 & 11 & - \\
\hline $\begin{array}{l}\text { Acinetobacter } \\
\text { ursinensis }\end{array}$ & $1(0.4 \%)$ & 1 & 24 & 24 & 24 & 8 & 22 & 24 & 20 & - \\
\hline Streptococcus spp. & $9(3.3 \%)$ & & & & & & & & & \\
\hline $\begin{array}{l}\text { Streptococcus } \\
\text { granulosus }\end{array}$ & $4(1.5 \%)$ & 4 & $8.5(0)$ & $26(15)$ & $18(14.5)$ & 19(11.25) & $18(15.25)$ & $8(0)$ & $28(17.5)$ & - \\
\hline
\end{tabular}

Notes: ${ }^{\mathrm{a}} \cdot \mathrm{n}(\%)$ : number of patients (percentage in the culture-positive group)

$\mathrm{b} * P<0.05$ in the Kruskal-Wallis $\mathrm{H}$ test

${ }^{\mathrm{c}} \mathrm{K}-\mathrm{B}$ : Kirby-Bauer 


\begin{tabular}{|c|c|c|c|c|c|c|c|c|c|c|}
\hline \multirow[t]{2}{*}{ Isolated bacteria } & \multirow[t]{2}{*}{$\mathrm{n}(\%)$} & \multirow{2}{*}{$\begin{array}{l}\text { Number } \\
\text { of K-B } \\
\text { test } \\
\text { results }\end{array}$} & \multicolumn{7}{|c|}{ Zone Diameter of Antimicrobial agent (mm) } & \multirow[t]{2}{*}{$P$} \\
\hline & & & Tobramycin & Ceftriaxone & Erythromycin & Vancomycin & Levofloxacin & Ofloxacin & Rifampin & \\
\hline $\begin{array}{l}\text { Streptococcus } \\
\text { sanguis }\end{array}$ & $3(1.1 \%)$ & 3 & $7(0)$ & $33(30)$ & $30(15)$ & $20(18)$ & 20(19) & $17(15)$ & $26(24)$ & - \\
\hline $\begin{array}{l}\text { Streptococcus } \\
\text { mitis }\end{array}$ & $1(0.4 \%)$ & 1 & 7 & 24 & 0 & 12 & 14 & 12 & 24 & - \\
\hline $\begin{array}{l}\text { streptococcus } \\
\text { parasanguis }\end{array}$ & $1(0.4 \%)$ & 1 & 10 & 24 & 0 & 14 & 9 & 9 & 30 & - \\
\hline Moraxella spp. & $8(2.9 \%)$ & 8 & $23(18.5)$ & $31(26.5)$ & $11(8.25)$ & $14(12.25)$ & $15(10.25)$ & $12.5(0)$ & $29(21.25)$ & 0.0 \\
\hline $\begin{array}{l}\text { Brevundimonas } \\
\text { spp. }\end{array}$ & $7(2.6 \%)$ & & & & & & & & & \\
\hline $\begin{array}{l}\text { Brevundimonas } \\
\text { diminuta }\end{array}$ & $6(2.2 \%)$ & 6 & $6(0)$ & 25(19) & $20(11.75)$ & $13.5(11.75)$ & $19(12.25)$ & 14.5(7.5) & $30(22.25)$ & 0.0 \\
\hline $\begin{array}{l}\text { Brevundimonas } \\
\text { vesicularis }\end{array}$ & $1(0.4 \%)$ & 1 & 0 & 24 & 22 & 16 & 24 & 22 & 28 & - \\
\hline Neisseria spp. & $3(1.1 \%)$ & & & & & & & & & \\
\hline Neisseria sicca & $2(0.7 \%)$ & 2 & $15.5(15)$ & $22(20)$ & $12.5(11)$ & $0(0)$ & $12(7)$ & $7.5(0)$ & $15(15)$ & - \\
\hline $\begin{array}{l}\text { Neisseria } \\
\text { longissima }\end{array}$ & $1(0.4 \%)$ & 1 & 22 & 0 & 8 & 21 & 22 & 22 & 30 & - \\
\hline Others & $53(19.3 \%)$ & & & & & & & & & \\
\hline $\begin{array}{l}\text { Inactive } \\
\text { biochemical } \\
\text { spectrum }\end{array}$ & $14(5.1 \%)$ & 14 & $12(0)$ & $30(16.75)$ & $16(12)$ & $20(9.5)$ & $11(0)$ & $8.5(0)$ & $27(15.5)$ & 0.0 \\
\hline $\begin{array}{l}\text { Unidentifiable } \\
\text { bacteria }\end{array}$ & $14(5.1 \%)$ & 12 & $19(14.5)$ & $29.5(24.5)$ & $17.5(10.5)$ & $19(9.5)$ & $23(17.75)$ & $16(11)$ & $26.5(17)$ & 0.0 \\
\hline $\begin{array}{l}\text { Dermatococcus } \\
\text { westermani }\end{array}$ & $4(1.5 \%)$ & 4 & $5(0)$ & $31(21)$ & $18(10.25)$ & $23.5(22)$ & $18(4)$ & $7(0)$ & $35.5(16)$ & - \\
\hline Coccus rhizophilus & $3(1.1 \%)$ & 3 & $8(0)$ & $26(14)$ & $17(10)$ & $22(18)$ & $32(18)$ & $14(0)$ & $30(28)$ & - \\
\hline Rosella carioides & $3(1.1 \%)$ & 3 & $14(9)$ & $26(22)$ & $15(10)$ & $20(20)$ & $22(16)$ & $14(0)$ & $26(20)$ & - \\
\hline $\begin{array}{l}\text { Aerococcus } \\
\text { viridans }\end{array}$ & $2(0.7 \%)$ & 2 & $12(0)$ & $32.5(28)$ & $17(0)$ & $20(16)$ & $24(16)$ & $19.5(13)$ & $26(18)$ & - \\
\hline $\begin{array}{l}\text { Aeromonas } \\
\text { Salmonella }\end{array}$ & $2(0.7 \%)$ & 2 & $20(18)$ & $23(22)$ & 19(19) & $12.5(9)$ & $28.5(27)$ & $25.5(24)$ & $21.5(20)$ & - \\
\hline $\begin{array}{l}\text { Sphingomonas } \\
\text { paucimobilis }\end{array}$ & $2(0.7 \%)$ & 2 & $8(0)$ & $21(14)$ & $5(0)$ & $23.5(17)$ & 19(8) & $12(0)$ & $29(24)$ & - \\
\hline $\begin{array}{l}\text { Alicyclobacillus } \\
\text { acidoterrestris }\end{array}$ & $1(0.4 \%)$ & 1 & 16 & 24 & 26 & 20 & 20 & 0 & 30 & - \\
\hline $\begin{array}{l}\text { Alloiococcus } \\
\text { otitidis }\end{array}$ & $1(0.4 \%)$ & 1 & 11 & 20 & 8 & 18 & 10 & 10 & 20 & - \\
\hline Escherichia coli & $1(0.4 \%)$ & 1 & 0 & 19 & 0 & 0 & 0 & 0 & 0 & - \\
\hline $\begin{array}{l}\text { Enterococcus } \\
\text { faecalis }\end{array}$ & $1(0.4 \%)$ & 1 & 13 & 0 & 20 & 16 & 18 & 15 & 0 & - \\
\hline $\begin{array}{l}\text { Morganella } \\
\text { morganii }\end{array}$ & $1(0.4 \%)$ & 1 & 13 & 21 & 0 & 0 & 20 & 16 & 9 & - \\
\hline Myroides spp. & $1(0.4 \%)$ & 1 & 0 & 30 & 16 & 15 & 12 & 0 & 28 & - \\
\hline $\begin{array}{l}\text { Klebsiella } \\
\text { pneumoniae }\end{array}$ & $1(0.4 \%)$ & 0 & & & & & & & & \\
\hline $\begin{array}{l}\text { Roseomonas } \\
\text { gilardii }\end{array}$ & $1(0.4 \%)$ & 1 & 24 & 18 & 14 & 0 & 18 & 16 & 12 & - \\
\hline
\end{tabular}

Notes: ${ }^{a} . \mathrm{n}(\%)$ : number of patients (percentage in the culture-positive group)

$\mathrm{b} * P<0.05$ in the Kruskal-Wallis $\mathrm{H}$ test

${ }^{\mathrm{c}}$ K-B: Kirby-Bauer 


\begin{tabular}{|c|c|c|c|c|c|c|c|c|c|c|}
\hline \multirow[t]{2}{*}{ Isolated bacteria } & \multirow[t]{2}{*}{$\mathrm{n}(\%)$} & \multirow{2}{*}{$\begin{array}{l}\text { Number } \\
\text { of K-B } \\
\text { test } \\
\text { results }\end{array}$} & \multicolumn{7}{|c|}{ Zone Diameter of Antimicrobial agent (mm) } & \multirow[t]{2}{*}{$P$} \\
\hline & & & Tobramycin & Ceftriaxone & Erythromycin & Vancomycin & Levofloxacin & Ofloxacin & Rifampin & \\
\hline $\begin{array}{l}\text { Stenotrophomonas } \\
\text { maltophilia }\end{array}$ & $1(0.4 \%)$ & 1 & 0 & 0 & 11 & 0 & 20 & 20 & 0 & - \\
\hline \multicolumn{11}{|c|}{ Notes: ${ }^{a} \cdot n(\%)$ : number of patients (percentage in the culture-positive group) } \\
\hline \multicolumn{11}{|c|}{$\mathrm{b} * P<0.05$ in the Kruskal-Wallis $\mathrm{H}$ test } \\
\hline${ }^{\mathrm{c}}$ K-B: Kirby-Bauer & & & & & & & & & & \\
\hline
\end{tabular}

Of the 234 identified cases with K-B test results, Staphylococcus epidermidis ( $n=40,17.1 \%)$ was the predominant organism. The results were retrieved and summarized in Table 5. According to the CLSI guideline, among 40 Staphylococcus epidermidis isolates, $100.0 \%$ were sensitive to vancomycin, $95.0 \%$ (38 of 40 isolates) to rifampin, $47.5 \%$ (19 of 40 isolates) to ceftriaxone, $37.5 \%$ (15 of 40 isolates) to tobramycin, $22.5 \%$ ( 9 of 40 isolates) to erythromycin, and $12.5 \%$ (5 of 40 isolates) to levofloxacin and ofloxacin.

Table 5

Results of K-B test of Staphylococcus spp.

\begin{tabular}{|c|c|c|c|c|c|c|c|c|}
\hline \multirow[t]{3}{*}{$\begin{array}{l}\text { Antimicrobial } \\
\text { agent }\end{array}$} & & $\begin{array}{l}\text { Staphylococcus } \\
\text { epidermidis }\end{array}$ & Staphylococcushominis & $\begin{array}{l}\text { Staphylococcus } \\
\text { warneri }\end{array}$ & $\begin{array}{l}\text { Staphylococcus } \\
\text { capitalis }\end{array}$ & $\begin{array}{l}\text { Staphylococcus } \\
\text { aureus }\end{array}$ & $\begin{array}{l}\text { Staphylococcus } \\
\text { auricularis }\end{array}$ & $\begin{array}{l}\text { Stak } \\
\text { capi }\end{array}$ \\
\hline & $\mathrm{n}$ & 56 & 7 & 4 & 2 & 1 & 1 & 1 \\
\hline & $\begin{array}{l}\text { Number } \\
\text { of K-B } \\
\text { test } \\
\text { results }\end{array}$ & 46 & 3 & 3 & 2 & 1 & 1 & 1 \\
\hline \multirow[t]{3}{*}{ Tobramycin } & $\mathrm{R}$ & 25 & 1 & 3 & 0 & 0 & 0 & 0 \\
\hline & I & 0 & 1 & 0 & 1 & 0 & 0 & 0 \\
\hline & $S$ & 15 & 0 & 0 & 0 & 0 & 1 & 1 \\
\hline \multirow[t]{3}{*}{ Ceftriaxone } & $\mathrm{R}$ & 14 & 0 & 2 & 1 & 0 & 0 & 0 \\
\hline & I & 7 & 1 & 0 & 0 & 0 & 1 & 0 \\
\hline & $S$ & 19 & 1 & 1 & 0 & 0 & 0 & 1 \\
\hline \multirow[t]{3}{*}{ Erythromycin } & $\mathrm{R}$ & 29 & 2 & 1 & 1 & 0 & 0 & 0 \\
\hline & I & 2 & 0 & 0 & 0 & 0 & 0 & 0 \\
\hline & $S$ & 9 & 0 & 2 & 0 & 0 & 1 & 1 \\
\hline \multirow[t]{3}{*}{ Vancomycin } & $\mathrm{R}$ & 0 & 0 & 0 & 0 & 0 & 0 & 0 \\
\hline & I & 0 & 0 & 0 & 0 & 0 & 0 & 0 \\
\hline & $S$ & 40 & 2 & 3 & 1 & 0 & 1 & 1 \\
\hline \multirow[t]{3}{*}{ Levofloxacin } & $\mathrm{R}$ & 34 & 1 & 1 & 1 & 0 & 0 & 0 \\
\hline & I & 1 & 0 & 1 & 0 & 0 & 0 & 0 \\
\hline & S & 5 & 1 & 1 & 0 & 0 & 1 & 1 \\
\hline \multirow[t]{3}{*}{ Ofloxacin } & $\mathrm{R}$ & 35 & 1 & 1 & 1 & 0 & 0 & 0 \\
\hline & 1 & 0 & 0 & 0 & 0 & 0 & 0 & 0 \\
\hline & $S$ & 5 & 1 & 2 & 0 & 0 & 1 & 1 \\
\hline \multirow[t]{3}{*}{ Rifampin } & $\mathrm{R}$ & 2 & 0 & 0 & 0 & 0 & 0 & 0 \\
\hline & 1 & 0 & 0 & 0 & 0 & 0 & 0 & 0 \\
\hline & $S$ & 38 & 2 & 3 & 1 & 0 & 1 & 1 \\
\hline \multicolumn{9}{|c|}{ Notes: ${ }^{a} \mathrm{n}$ : number of patients } \\
\hline \multicolumn{9}{|c|}{${ }^{\mathrm{b}} \mathrm{K}-\mathrm{B}$ test: Kirby-Bauer disk diffusion test } \\
\hline
\end{tabular}


It should be noted that the majority of Staphylococcus epidermidis (33 of 40 isolates, $82.5 \%$ ) isolated samples had multidrug resistance to 3 kinds of antimicrobial agents or more. Further, $22.5 \%$ (9 of 40 isolates) were resistant to 3 kinds, $40.0 \%$ (16 of 40 isolates) to 4 kinds, and $20.0 \%$ ( 8 of 40 isolates) to 5 kinds. The Upsetview of multidrug resistance of Staphylococcus epidermidis is shown in Fig. 2.

\subsection{Subgroup classified by clinical factors}

\subsubsection{Gender}

Among the 274 culture-positive samples, $50.0 \%(n=137)$ were from male patients, and the rest $(n=137)$ were from females. For male culture-positive patients, Staphylococcus epidermidis $(n=31,22.6 \%)$, Kocuria rosea $(n=18,13.1 \%)$, Kocuria kristinae $(n=13,9.5 \%)$, Micrococcus luteus ( $n=11,8.0 \%)$, and Kocuria varians $(n=7,5.1 \%)$ were the 5 strains with the highest positive rates, accounting for $58.4 \%$ of culture-confirmed cases. For female culture-positive samples, Staphylococcus epidermidis $(n=25,18.2 \%)$ was still the most prevalent culture-positive strain, followed by Micrococcus luteus ( $n=21,15.3 \%)$ and Kocuria rosea $(n=18,13.1 \%)$. These 3 strains accounted for $46.7 \%$ of the culture-confirmed cases. It should be noted that the number of Staphylococcus epidermidispositive isolates in the male patient group $(n=31,22.6 \%)$ was more than that in the female patient group $(n=25,18.2 \%)$, and there was significant difference between the two groups $(X 2=7.139, P<0.05)$. There was no significant difference in $K-B$ results for various antimicrobial agents between the male and female patients.

\subsubsection{Hypertension}

Patients with hypertension had more positive culture results than those without hypertension $(\mathrm{P}<0.05)$. Among culture-positive patients with hypertension, there were $18.1 \%(n=27)$ with Staphylococcus epidermidis, $14.1 \%(n=21)$ with Micrococcus luteus, and $12.1 \%(n=18)$ with Kocuria rosea. For culture-positive patients without hypertension, Staphylococcus epidermidis $(n=29,23.2 \%)$, Kocuria rosea $(n=19,15.2 \%)$, and Kocuria kristinae $(n=11,8.8 \%)$ were the 3 most prevalent strains. Compared to the hypertension patient group $(n=21,14.1 \%)$, Micrococcus luteus $(n=11,8.8 \%)$ was less frequently found in patients without hypertension. There was statistically significant difference between the two groups $(X 2=9.829, P<0.05)$.

As for K-B test results, the median zone diameter of Staphylococcus epidermidis for ofloxacin in the hypertension group (0mm) was smaller than that in the non-hypertension group $(9 \mathrm{~mm})$, and there was a significant difference between two groups $(P<0.05)$. However, this could be related to use of levofloxacin preoperatively and requires careful analysis.

\subsubsection{Diabetes mellitus}

The 4 strains with the highest positive culture rates in the DM group were the same as the strains in the non-DM group, namely Staphylococcus epidermidis (n $=22,25.0 \%$ of patients with DM; $n=34,18.3 \%$ of patients without DM), Kocuria rosea $(n=12,13.6 \%$ of patients with $D M ; n=25,13.4 \%$ of patients without DM), Micrococcus luteus ( $n=12,13.6 \%$ of patients with $D M ; n=25,13.4 \%$ of patients without DM), and Kocuria kristinae ( $n=5,5.7 \%$ of patients with $D M$; $n=$ $14,7.5 \%$ of patients without DM). The number of Staphylococcus epidermidis-positive samples of non-diabetic patients ( $n=34,18.3 \%)$ was greater than the number among diabetic patient samples $(n=22,25.0 \%)$, and there was a significant difference between the two groups $(X 2=8.865, P<0.05)$. The information of K-B test results was also retrieved, and there was no significant difference between the diabetes group and non-diabetes group.

\subsubsection{Comprehensive analysis of related clinical factors}

After comprehensive analysis of all related clinical factors, we identified 27 ( $9.9 \%$ of all positive samples) male patients with both hypertension and diabetes mellitus. Staphylococcus epidermidis was the most detected strain $(n=9,33.3 \%)$. The proportion of Staphylococcus epidermidis was highest in the male group (22.6\%), the hypertension group (18.1\%), and the DM group (25.0\%). There were significant differences for various antimicrobial agents in the K-B test $(\mathrm{P}<0.05)$, and the zone diameters of rifampin were largest of all the antimicrobial agents (median zone diameter was $32 \mathrm{~mm})$. As shown in the Fig. 3 , the median zone diameter of rifampin in samples from males with hypertension and DM (32 $\mathrm{mm})$ was larger than that in the male group (28mm), hypertension group (30mm), and DM group $(29 \mathrm{~mm})$. There were no significant differences between groups $(P>0.05)$.

\section{Discussion}

This study systematically retrieved real-world Data (RWD) of 15,415 cases of patients that had used levofloxacin eye drops preoperatively. Data was retrieved from published literature from the last 10 years and from patients that had come to Peking University Third Hospital from 2016 to 2019 . According to previous study results, the positive rate of bacterial cultures of the conjunctival sac in healthy adults is about $20 \%[24]$. In the current study, the results revealed that by topically applying levofloxacin preoperatively, the positive rate of bacterial cultures from the conjunctival sac had dramatically decreased to $1.8 \%$, indicative of the strong antimicrobial effect of levofloxacin in application before cataract surgery. However, it should be noted that even if levofloxacin had been used four times a day for 3 days, the possibility of a positive conjunctival sac bacterial culture still remained. Due to residual bacteria in the conjunctival sac, culturepositive patients were still at risk of endophthalmitis and other infectious diseases. Historically, the incidence of post-cataract surgery endophthalmitis ranges from $0.03-0.70 \%$ which could lead to serious consequences $[25 ; 26]$. As shown in Table 6 , there are several major pathogens isolated from conjunctival sac of patients with post-cataract surgery endophthalmitis $[5 ; 21 ; 27-36]$. Among them, Gram-positive bacteria is the major pathogen and Coagulase-negative Staphylococci is the most frequently isolated strain $[5 ; 21 ; 30 ; 31 ; 34-36]$. According to Egrilmez et al, Coagulase-negative Staphylococci shows resistance rates of more than $30 \%$ for fluoroquinolone and methicillin [37]. In addition to endophthalmitis, it can also lead to other infectious diseases including bacterial keratitis. Without effective antibiotic prophylactic therapy, patient may be at risk of potentially vision-threatening infection. 
Table 6

Summary of major pathogens involved in post-cataract surgery endophthalmitis

\begin{tabular}{|c|c|c|}
\hline $\begin{array}{l}\text { Year of } \\
\text { Publication }\end{array}$ & Major Pathogen & References \\
\hline 2005 & Pseudomonas aeruginosa & $\begin{array}{l}\text { Kenchappa } \\
\text { et al(27) }\end{array}$ \\
\hline 2009 & Pseudomonas aeruginosa & $\begin{array}{l}\text { Pinna et } \\
\text { al(28) }\end{array}$ \\
\hline 2009 & Stenotrophomonas maltophilia & $\begin{array}{l}\text { Horster et } \\
\text { al(29) }\end{array}$ \\
\hline 2011 & Gram-positive bacteria (65.2\%) & $\begin{array}{l}\text { Ding et } \\
\text { al(30) }\end{array}$ \\
\hline 2013 & Coagulase-negative Staphylococci & $\begin{array}{l}\text { Durand et } \\
\text { al(31) }\end{array}$ \\
\hline 2015 & Coagulase-negative Staphylococci & $\begin{array}{l}\text { Chiquet et } \\
\text { al(21) }\end{array}$ \\
\hline 2015 & Stenotrophomonas maltophilia (57.1\%) & Ji et al(32) \\
\hline 2015 & Pseudomonas aeruginosa & $\begin{array}{l}\text { Priya et } \\
\text { al(33) }\end{array}$ \\
\hline 2017 & Coagulase-negative Staphylococci (70\%), Staphylococcus aureus (10\%), Streptococci (9\%) & Durand(5) \\
\hline 2017 & Gram-positive bacteria ( $96 \%$, Coagulase-negative Staphylococci is the most, accounting for $52 \%$ ) & $\begin{array}{l}\text { Slean et } \\
\text { al(34) }\end{array}$ \\
\hline 2018 & $\begin{array}{l}\text { Gram-positive bacteria (95\%), including Coagulase-negative Micrococci (Staphylococcus) } 70 \% \text {, Staphylococcus aureus } \\
10 \% \text {, Streptococcus species } 9 \% \text {, Enterococcus species } 2.2 \%\end{array}$ & $\begin{array}{l}\text { Rahmani et } \\
\text { al(35) }\end{array}$ \\
\hline 2018 & Gram-negative bacteria (5\%), including Pseudomonas, Proteus, and Haemophilus Influenzae & $\begin{array}{l}\text { Rahmani et } \\
\text { al(35) }\end{array}$ \\
\hline 2019 & Gram-positive bacteria ( $89 \%$, Staphylococcus is the most, accounting for $67 \%$ ) & $\begin{array}{l}\text { Slipa-Archa } \\
\text { et al(36) }\end{array}$ \\
\hline
\end{tabular}

According to our results, Staphylococcus epidermidis, Kocuria rosea, and Micrococcus luteus were the 3 strains with the highest culture-positive rates after usage of levofloxacin eye drops for 3 days preoperatively. All of these bacteria belong to the family Micrococcaceae and are commensals, which can be found on human skin, mucous membranes, and the conjunctival sac [38; 39]. They can cause opportunistic infections, requiring considerable attention [40]. Staphylococcus epidermidis is considered non-pathogenic. However, patients with a compromised immune system are often at risk of being infected. Characteristically, infections caused by Staphylococcus epidermidis are often chronic, which contrasts the acute infections caused by Staphylococcus aureus [41]. The pathogenesis of Staphylococcus epidermidis infection usually involves the formation of biofilms and phenol-soluble modulins which can kill human red and white blood cells [42-44]. It has been reported that Staphylococcus epidermidis cause biofilm growth on intravenous catheters and medical prostheses [45]. Thus, patients with Staphylococcus epidermidis are at risk of infection after implantation of intraocular lenses during cataract surgery. Besides, Kocuria rosea and Micrococcus luteus can also cause infectious disease in immunocompromised hosts. It has been reported that Kocuria rosea can cause meningitis, canaliculitis, endocarditis, and descending necrotizing mediastinitis [46-52]. As an opportunistic pathogen, Micrococcus luteus can also cause serious infections, such as endocarditis and brain abscess [53; 54]. Our study shows that patients with certain clinical factors (male gender, the presence of hypertension or diabetes mellitus) are at risk of having a greater conjunctival sac bacterial load, which has been confirmed in previous studies [55-58]. These factors are often present in patients, which may lead to immunocompromised hosts and resulting ocular opportunistic infections caused by the above-mentioned bacteria[1]. It is therefore suggested that ophthalmologists pay more attention to patients with any of these three clinical factors. As for the antibiotic resistance of conjunctival sac bacteria, we found that the resistance of Staphylococcus epidermidis against ofloxacin in the hypertension group was stronger than in the non-hypertension group $(P<0.05)$. However, the result cannot explain a direct relationship between hypertension and antibiotic resistance of bacteria and how these relate to the preoperative use of levofloxacin. Levofloxacin, a fluoroquinolone, is an isomer of ofloxacin [59]. By using levofloxacin preoperatively, ofloxacin-sensitive bacteria were widely eliminated in patients, and the ratio of ofloxacin-resistant bacteria in patient conjunctival sacs was relatively increased. This may have influenced the results of the current study.

The fact that there still were culture-positive samples after three days of antibiotic prophylactic treatment with levofloxacin shows that, in addition to a high conjunctival sac bacterial load, another possible reason could be the drug resistance of these bacteria. With the widespread use of antibiotics, antimicrobial resistance rates have gradually increased [14; 15]. In the current study, several kinds of bacterial strains were reported as resistant to antimicrobial agents, especially to levofloxacin and ofloxacin. Among them, several Staphylococcus epidermidis isolates had multidrug resistance to antimicrobial agents. It is commonly believed that antimicrobial resistance is higher in Staphylococcus epidermidis than in other Coagulase-negative Staphylococcus spp. [60]. The resistance of these bacterial strains against levofloxacin has been confirmed in several studies and has raised questions regarding the use of particular antimicrobial agents for routine prophylaxis [17-21].

In order to further decrease the conjunctival sac bacterial load through antibiotic prophylactic therapy, we need to carefully consider combinations of other effective antimicrobial agents. Our study suggests that rifampin would be a good choice for better topical prophylactic therapy, since most bacteria were sensitive to that agent. Rifampin belongs to rifamycins and has activity against several types of bacteria. Fernández Rubio et al. pointed out that $83.9 \%$ of 
conjunctival sac bacteria were sensitive to rifampin. Rifampin was the most effective for the eradication of the whole, predominantly Gram-positive, flora [61]. According to Chojnacki et al., the rifampin plus polymyxin B-trimethoprim combination demonstrated synergistic antimicrobial activity towards ocular clinical Staphylococcus aureus and Pseudomonas aeruginosa isolates, a low spontaneous resistance frequency, and in vitro bactericidal kinetics and antibiofilm activities equal to or exceeding those of moxifloxacin [62]. Compared to literature on the clinical effects of other antibiotics (Table 7), our study revealed a higher sensitivity of conjunctival sac bacteria towards rifampin[8; 63-73]. Further, there was not enough evidence for side effects of the topical application of rifampin at low concentrations.

Table 7

Summary of antibiotic studies

\begin{tabular}{|c|c|c|c|}
\hline Antibiotic & $\begin{array}{l}\text { Patients/eye } \\
\text { number }\end{array}$ & Effects & References \\
\hline Cefuroxime & $\begin{array}{l}2434008 \\
\text { patients/ } \\
3351401 \\
\text { eyes }\end{array}$ & $\begin{array}{l}\text { The intracameral injection of cefuroxime at the end of cataract surgery is associated with a lower } \\
\text { risk of postoperative endophthalmitis and is safe for patients with or without a perioperative } \\
\text { capsular rupture. }\end{array}$ & $\begin{array}{l}\text { Daien et al., } \\
2016(63)\end{array}$ \\
\hline Gatifloxacin & $\begin{array}{l}204515 \\
\text { patients }\end{array}$ & $\begin{array}{l}\text { Intracameral antibiotic was more effective for preventing post-cataract extraction endophthalmitis } \\
\text { than topical antibiotic alone. }\end{array}$ & $\begin{array}{l}\text { Herrinton et } \\
\text { al., 2016(64) }\end{array}$ \\
\hline $\begin{array}{l}\text { Third-generation } \\
\text { fluoroquinolone, } \\
\text { fourth-generation } \\
\text { fluoroquinolone, } \\
\text { tobramycin }\end{array}$ & 75318 eyes & $\begin{array}{l}\text { Preoperative and the operation day antibiotics have no influence on postoperative } \\
\text { endophthalmitis rate. }\end{array}$ & $\begin{array}{l}\text { Rudnisky et } \\
\text { al., 2014(65) }\end{array}$ \\
\hline Levofloxacin $1.5 \%$ & $\begin{array}{l}96 \\
\text { patients } / 96 \\
\text { eyes }\end{array}$ & $\begin{array}{l}\text { The positive rate of conjunctival sac bacterial culture decreases from } 78.1 \% \text { to about } 11.5 \% \text {; } \\
\text { Levofloxacin has good safety and effectiveness in conjunctival sac eradication, especially for } \\
\text { Gram-positive bacteria, but is not as effective for Propionibacterium acnes. }\end{array}$ & $\begin{array}{l}\text { Suzuki et al., } \\
2013(8)\end{array}$ \\
\hline Ciprofloxacin $0.3 \%$ & $\begin{array}{l}46 \\
\text { patients } / 46 \\
\text { eyes }\end{array}$ & $\begin{array}{l}\text { The administration of } 0.3 \% \text { ciprofloxacin significantly reduced colony-forming units compared } \\
\text { with the control group }(P<0.05) \text {. }\end{array}$ & $\begin{array}{l}\text { Carron et al., } \\
2013(66)\end{array}$ \\
\hline $\begin{array}{l}\text { Levofloxacin, } \\
\text { gentamycin, } \\
\text { chloramphenicol, } \\
\text { fusidic acid }\end{array}$ & 464996 eyes & $\begin{array}{l}\text { Among patients treated with preoperative antibiotics and intracameral antibiotics, there were eight } \\
\text { cases of postoperative endophthalmitis }(0.017 \%), P=0.29 \text { vs. group with intracameral antibiotic } \\
\text { alone. Addition of preoperative antibiotic does not reduce the risk of postoperative } \\
\text { endophthalmitis. }\end{array}$ & $\begin{array}{l}\text { Friling et al., } \\
2013(67)\end{array}$ \\
\hline $\begin{array}{l}\text { Antibiotic } \\
\text { (ofloxacin) vs. } \\
\text { antiseptic } \\
\text { (hexamidine di- } \\
\text { isetionate) eye } \\
\text { drops }\end{array}$ & $\begin{array}{l}58 \\
\text { patients } / 60 \\
\text { eyes }\end{array}$ & Antibiotic and antiseptic eye drops had similar results in disinfection of the conjunctival sac. & $\begin{array}{l}\text { Vaninbroukx } \\
\text { et al., } \\
2010(68)\end{array}$ \\
\hline Moxifloxacin $0.5 \%$ & 144 patients & $\begin{array}{l}\text { The positive rate of conjunctival sac bacterial culture decreases to about } 35 \% .1 \text { day and } 3 \text { days of } \\
\text { therapy with moxifloxacin had the same efficacy in decontamination of the conjunctival sac, but } 1 \\
\text { day of prophylactic treatment with moxifloxacin resulted in a significant increase of resistance to } \\
\text { fluoroquinolones; moxifloxacin treatment for } 3 \text { days did not cause an increase in resistance. }\end{array}$ & $\begin{array}{l}\text { He et al., } \\
2009(69)\end{array}$ \\
\hline Moxifloxacin $0.5 \%$ & 148 patients & $\begin{array}{l}93 \% \text { reduction of CFU; Application of moxifloxacin on the day of surgery is effective in reducing } \\
\text { colony-forming units. }\end{array}$ & $\begin{array}{l}\text { Vasavada et } \\
\text { al., 2008(70) }\end{array}$ \\
\hline $\begin{array}{l}\text { Gatifloxacin } 0.3 \% \\
\text { vs. moxifloxacin } \\
0.5 \%\end{array}$ & 220 patients & There was no difference between the two antibiotics. & $\begin{array}{l}\text { Bucci et al., } \\
2008(71)\end{array}$ \\
\hline Netilmicin & $\begin{array}{l}56 \\
\text { patients } / 56 \\
\text { eyes }\end{array}$ & $\begin{array}{l}\text { Coagulase negative staphylococci was positive in } 9.93 \% \text { of patients after treatment; } 83.9 \% \text { of } \\
\text { samples had no bacterial growth; Staphylococcus aureus was eliminated after treatment. }\end{array}$ & $\begin{array}{l}\text { Aslan et al., } \\
2008(72)\end{array}$ \\
\hline Gatifloxacin & $\begin{array}{l}60 \\
\text { patients } / 120 \\
\text { eyes }\end{array}$ & Reduction of CFU: 67 to $28 \%$ (1 day); 60 to $37 \%$ ( 1 h); 67 to $18 \%$ (1 day. 1 h) & $\begin{array}{l}\text { Moss et al., } \\
2008(73)\end{array}$ \\
\hline
\end{tabular}

Although rifampin is a good choice for combination therapy, it may lead to multidrug resistance and more severe consequences, including fever, headache, orange tears, skin redness or rash (allergic reaction) and other symptoms. Usage of multiple antimicrobial agents can effectively reduce bacterial load in the conjunctival sac. However, more resistant strains can also develop as a result of combined treatment. Therefore, simply adding more antimicrobial agents is an unsustainable strategy for improving antibiotic prophylactic therapy. Furthermore, patients may be at a greater risk of infectious diseases, and the proportion of antibiotic abuse may be higher due to clinical factors. The bacterial flora of the ocular surface may have already been multidrug-resistant in these patients. Thus, local application of multiple antibiotics may aggravate the risk of multidrug resistance.

Alternatively, we advocate a variety of other methods for decreasing the conjunctival sac bacterial load without using more antibiotics. Usage of povidone iodine (PVI) for irrigation during operation can reduce the bacterial burden in the conjunctival sac and has been proven as effective [74]. According to available literature (Table 8), the irrigation with high concentrations of PVI (5\%-10\%) can effectively decrease the conjunctival bacterial flora. PVI (5\%) solution does not increase antimicrobial resistance and has no adverse effects. Low-concentration PVI ( $0.05 \%)$ irrigation of the conjunctival sac for $30 \mathrm{~s}$ can achieve a low bacterial contamination rate and reduce damage to the ocular surface. Levofloxacin can enhance the effectiveness of conjunctival sac irrigation with PVI solution [10; 75-86]. Compared to the preoperative use of topical antibiotics, the use of PVI can achieve the same degree of elimination of conjunctival sac 
bacteria. However, appropriate PVI concentration and irrigation duration should be precisely controlled, or it may cause damage to the ocular surface. Preoperative topical antibiotic treatment could be used as an additional method for further elimination of conjunctival sac bacteria.

Table 8

Summary of povidone-iodine studies (PVI)

\begin{tabular}{|c|c|c|c|}
\hline Analyzed chemotherapeutic & $\begin{array}{l}\text { Patients/eyes } \\
\text { number }\end{array}$ & Effects & References \\
\hline $0.05 \% \mathrm{PVI}$ & $\begin{array}{l}90 \\
\text { patients } / 90 \\
\text { eyes }\end{array}$ & $\begin{array}{l}0.05 \% \text { PVI irrigation of the conjunctival sac for } 30 \mathrm{~s} \text { can achieve a low } \\
\text { bacterial contamination rate. Importantly, it reduced the damage of the } \\
\text { ocular surface, which is beneficial for the recovery of ocular surface } \\
\text { function. }\end{array}$ & $\begin{array}{l}\text { Fan et al., } \\
2019(75)\end{array}$ \\
\hline $0.3 \% \mathrm{PVI}$ & $\begin{array}{l}51 \\
\text { participants }\end{array}$ & $\begin{array}{l}\text { Preoperative treatment with long-term, low-concentration PVI applied via a } \\
\text { depot device to the fornix inferior seems to be an easy and effective way to } \\
\text { reduce the number of bacterial colonies in the conjunctiva (66.7-23.4\%). }\end{array}$ & $\begin{array}{l}\text { Wass et } \\
\text { al., } \\
2019(76)\end{array}$ \\
\hline $10 \% \mathrm{PVI} 3 \mathrm{~min}$ & 604 patients & $\begin{array}{l}\text { Implementation of a preoperative prophylaxis protocol that used PVI } 10 \% \\
\text { with a 3-minute exposure time can be performed in clinical practice. The } 3 \text { - } \\
\text { minute exposure time had no adverse sequelae. }\end{array}$ & $\begin{array}{l}\text { Nguyen et } \\
\text { al., } \\
2019(77)\end{array}$ \\
\hline $0.33 \% \mathrm{PVI}$ & $\begin{array}{l}99 \text { patients/ } \\
198 \text { eyes }\end{array}$ & $\begin{array}{l}\text { Timely iodine irrigation can serve as a simple and useful adjunctive } \\
\text { disinfection step in cataract surgery. The bacterial DNA copy number } \\
\text { decreased from } 1.7 \pm 0.5 \times 10^{3} \text { to } 1.7 \pm 0.6 \times 10^{4}\end{array}$ & $\begin{array}{l}\text { Matsuura } \\
\text { et al., } \\
2016(78)\end{array}$ \\
\hline \multirow[t]{2}{*}{$5 \% \mathrm{PVI}$} & $\begin{array}{l}13 \text { eyes } \\
\text { before serial } \\
\text { intravitreal }\end{array}$ & \multirow[t]{2}{*}{$\begin{array}{l}5 \% \text { PVI solution does not increase antimicrobial resistance and has no } \\
\text { adverse effects on the conjunctival bacterial flora. }\end{array}$} & \multirow[t]{2}{*}{$\begin{array}{l}\text { Hsu et al., } \\
2014(79)\end{array}$} \\
\hline & $\begin{array}{l}\text { injection; } 48 \\
\text { cultures } \\
\text { performed }\end{array}$ & & \\
\hline Levofloxacin $0.3 \%+$ PVI 1 vs. 5 vs. $10 \%$ & 271 patients & $\begin{array}{l}10 \% \text { PVI solution was most effective in the reduction of the bacterial flora } \\
\text { in the conjunctival sac. Most common isolated bacteria were coagulase- } \\
\text { negative Staphylococcocus spp. }\end{array}$ & $\begin{array}{l}\text { Li et al., } \\
2013(80)\end{array}$ \\
\hline $\begin{array}{l}10 \% \text { PVI drops vs. irrigation of the } \\
\text { conjunctival sac with } 1 \% \mathrm{PVI}\end{array}$ & $\begin{array}{l}242 \\
\text { patients } / 263 \\
\text { eyes }\end{array}$ & $\begin{array}{l}\text { Three drops of } 10 \% \mathrm{PVI} \text { prior to surgery, followed by preoperative irrigation } \\
\text { of the conjunctiva with } 1 \% \mathrm{PVI} \text {, provides additional reduction in } \\
\text { conjunctival sac bacterial cultures (positive rate reduced from } 69-93 \% \text { to } \\
1-16 \% \text { ). }\end{array}$ & $\begin{array}{l}\text { Nentwich } \\
\text { et al., } \\
2012(81)\end{array}$ \\
\hline $\begin{array}{l}0.3 \% \text { Ciprofloxacin vs. } 0.3 \% \text { Ofloxacin vs. } \\
5 \% \text { PVI }\end{array}$ & $\begin{array}{l}164 \text { patients/ } \\
164 \text { eyes }\end{array}$ & $\begin{array}{l}\text { Ciprofloxacin was the most effective in bacterial eradication }(72.2-8.0 \%) \text {. } \\
\text { PVI solution (75.4-22.7\%) was more effective than Ofloxacin (59.6- } \\
33.4 \%) \text {. }\end{array}$ & $\begin{array}{l}\text { Coskun et } \\
\text { al., } \\
2011(82)\end{array}$ \\
\hline $5 \% \mathrm{PVI}$ & $\begin{array}{l}221 \text { patients/ } \\
224 \text { eyes }\end{array}$ & $\begin{array}{l}5 \% \mathrm{PVI} \text { is effective for the reduction of bacterial flora and reduction of } \\
\text { bacterial growth (from } 73.2 \text { to } 12.5 \% \text { ). }\end{array}$ & $\begin{array}{l}\text { Quiroga et } \\
\text { al., } \\
2010(83)\end{array}$ \\
\hline $5 \% \mathrm{PVI}$ solution & $\begin{array}{l}54 \text { patients/ } \\
54 \text { eyes }\end{array}$ & $\begin{array}{l}5 \% \text { PVI for } 3 \text { min significantly reduced positive cultures; A reduction of the } \\
\text { proportion of positive swabs from } 87 \text { to } 30 \% \text {. }\end{array}$ & $\begin{array}{l}\text { Carrim et } \\
\text { al., } \\
2009(84)\end{array}$ \\
\hline $\begin{array}{l}\text { Moxifloxacin } 5 \text { and } \\
5 \% \text { povidone- iodine }(\mathrm{PVI}) \text { vs. } 5 \% \mathrm{PVI}\end{array}$ & 464 patients & $\begin{array}{l}\text { Therapy with } 5 \% \mathrm{PVI} \text { solution is effective in the reduction of positive } \\
\text { conjunctival cultures. Adding } 0.5 \% \text { moxifloxacin had no significant effect in } \\
\text { the reduction of conjunctival bacteria. }\end{array}$ & $\begin{array}{l}\text { Halachmi- } \\
\text { Eyal et al., } \\
2009(85)\end{array}$ \\
\hline $\begin{array}{l}0.5 \% \text { Levofloxacin } \\
\text { (LVFL) and } 1 \% \mathrm{PVI} \\
\text { solution vs. } 1 \%\end{array}$ & \multirow[t]{2}{*}{$\begin{array}{l}140 \text { patients/ } \\
140 \text { eyes }\end{array}$} & \multirow[t]{2}{*}{$\begin{array}{l}\text { Levofloxacin enhanced effectiveness of irrigation of the conjunctival sac } \\
\text { with PVI solution. }\end{array}$} & \multirow[t]{2}{*}{$\begin{array}{l}\text { Min o de } \\
\text { Kaspar et } \\
\text { al., } \\
2008(86)\end{array}$} \\
\hline $\begin{array}{l}\text { PVI solution } \\
\text { alone }\end{array}$ & & & \\
\hline $\begin{array}{l}\text { Levofloxacin } 0.5 \% \text { (LVFX) ophthalmic } \\
\text { solution vs. } 16 \text {-fold dilution of PVI solution } \\
\text { vs. } 6 \text {-fold dilution of polyvinyl alcoholiodine } \\
\text { (PAI) solution }\end{array}$ & $\begin{array}{l}272 \text { patients/ } \\
272 \text { eyes }\end{array}$ & $\begin{array}{l}\text { 3-day therapy with LVFX and eyewash with diluted iodine solution is } \\
\text { effective in disinfection of the conjunctival sac. It is impossible to eliminate } \\
\text { all of bacteria from the conjunctival sac (Propionibacterium acnes and } \\
\text { Staphylococcus epidermidis). }\end{array}$ & $\begin{array}{l}\text { Inoue et } \\
\text { al., } \\
2008(10)\end{array}$ \\
\hline
\end{tabular}

We must admit that our study still has limitations. Due to a lack of information, some statistical analyses could not be conducted and we may not provide unexpected results. Not all clinical factors related to conjunctival sac bacterial load were analyzed in our study due to missing data, including age, history of cancer, and screening for infectious diseases. These factors cannot be ignored and would have to be investigated in a follow-up study. However, this limited result can still arouse our attention to the drug-resistance of conjunctival sac bacteria and provide suggestions for preventive treatment.

\section{Conclusions}

Male gender and the presence of hypertension and diabetes mellitus are clinical risk factors for a greater conjunctival sac bacterial load. In order to decrease the conjunctival sac bacterial load for the prevention of possible infections, we offer a prophylaxis suggestion based on real-world data, namely the combined 
use of levofloxacin and rifampin. However, such combined therapy but may aggravate the risk of multidrug resistance. Therefore, alternative ways should be suggested.

\section{Declarations}

\section{Funding}

This work was supported by the National Science and Technology Major Project 2018ZX, grant number 10101004003003.

\section{Competing interests}

The authors declare no conflict of interest.

\section{Availability of data and materials}

The datasets used and analyzed during the current study are available from the corresponding author on reasonable request.

\section{Authors' contributions}

Zhenyu Wang, Pei Zhang, and Chen Huang analyzed the patient data and were major contributors in the writing of the manuscript. Yining Guo, Xuhe Dong, and Xuemin Li retrieved all the real-world data of patients. All authors read and approved the final manuscript.

\section{Ethics approval and consent to participate}

All participating individuals provided informed consent according to the tenets of the Declaration of Helsinki. The Medical Ethics Committee of Peking University Third Hospital (Beijing, China) approved all procedures of the present study (approval number: M2019432).

\section{Consent for publication}

Not required.

\section{Acknowledgements}

Not applicable

\section{References}

1. Kawata T, Matsuo T. Positive bacterial culture in conjunctival sac before cataract surgery with night stay is related to diabetes mellitus. BMC Ophthalmol. 2017;17(1):14. 10.1186/s12886-017-0413-7.

2. Stern GA, Engel HM, Driebe WT Jr. Recurrent postoperative endophthalmitis Cornea. 1990;9(2):102-7.

3. Hara J, Yasuda F, Higashitsutsumi M. (1997) Preoperative disinfection of the conjunctival sac in cataract surgery. Ophthalmologica 211 Suppl 1 (62-67. $10.1159 / 000310888$.

4. Pinna A, Sechi LA, Zanetti S, Carta F. Detection of virulence factors in a corneal isolate of Klebsiella pneumoniae. Ophthalmology. 2005;112(5):883-7. 10.1016/j.ophtha.2004.12.024.

5. Durand ML. Bacterial and Fungal Endophthalmitis. Clin Microbiol Rev. 2017;30(3):597-613. 10.1128/CMR.00113 - 16.

6. Deepthi KG, Jayasudha R, Girish RN, Manikandan P, Ram R, Narendran V, Prabagaran SR. Polybacterial community analysis in human conjunctiva through 16S rRNA gene libraries. Exp Eye Res. 2018;174:1-12. 10.1016/j.exer.2018.05.011.

7. Suzuki T, Yamamoto T, Ohashi Y. The antibacterial activity of levofloxacin eye drops against staphylococci using an in vitro pharmacokinetic model in the bulbar conjunctiva. J Infect Chemother. 2016;22(6):360-5. 10.1016/j.jiac.2016.01.011.

8. Suzuki T, Tanaka H, Toriyama K, Okamoto S, Urabe K, Hashida M, Shinkai Y, Ohashi Y. Prospective clinical evaluation of $1.5 \%$ levofloxacin ophthalmic solution in ophthalmic perioperative disinfection. J Ocul Pharmacol Ther. 2013;29(10):887-92. 10.1089/jop.2013.0146.

9. Gong L, Sun XH, Qiu XD, Zhang YQ, Qu J, Yuan ZL, Xiong QC. [Comparative research of the efficacy of the gatifloxacin and levofloxacin for bacterial conjunctivitis in human eyes]. Zhonghua Yan Ke Za Zhi. 2010;46(6):525-31.

10. Inoue Y, Usui M, Ohashi Y, Shiota H, Yamazaki T, Preoperative Disinfection Study G. Preoperative disinfection of the conjunctival sac with antibiotics and iodine compounds: a prospective randomized multicenter study. Jpn J Ophthalmol. 2008;52(3):151-61. 10.1007/s10384-008-0517-y.

11. Cai HY, Chen XY, Hong J. [Clinical study on the reduction of ocular surface bacteria in pre-operative cataract surgery patients by cleansing the eyelid margins]. Zhonghua Yan Ke Za Zhi. 2018;54(6):445-51. 10.3760/cma.j.issn.0412-4081.2018.06.011.

12. Zhang SD, He JN, Niu TT, Liu SS, Chan CY, Ren CY, Liu C, Pang CP, Qu Y, Li RX, Wang HL. Effectiveness of meibomian gland massage combined with topical levofloxacin against ocular surface flora in patients before penetrating ocular surgery. Ocul Surf. 2018;16(1):70-6. 10.1016/j.jtos.2017.09.001.

13. Li X, Liang X, Tang L, Zhang J, Shen L, Su G, Li X. Optimal Duration for the Use of $0.5 \%$ LevofloxacinEye Drops Before Vitreoretinal Surgery. Asia Pac J Ophthalmol (Phila). 2017;6(1):40-4. 10.22608/AP0.2015197.

14. Niu G, Li W. Next-Generation Drug Discovery to Combat Antimicrobial Resistance. Trends Biochem Sci. 2019;44(11):961-72. 10.1016/j.tibs.2019.05.005. 
15. Ortega-Pena S, Martinez-Garcia S, Rodriguez-Martinez S, Cancino-Diaz ME, Cancino-Diaz JC. Overview of Staphylococcus epidermidis cell wall-anchored proteins: potential targets to inhibit biofilm formation. Mol Biol Rep. 2019. 10.1007/s11033-019-05139-1.

16. Lazicka-Galecka M, Galecki T, Szaflik JP. [A review of safety and efficacy of levofloxacin $0.5 \%$ ophthalmic solution in the treatment of external ocular infections and in prophylaxis of postoperative endophthalmitis]. Klin Oczna. 2015;117(2):123-9.

17. Fernandez-Rubio ME. (2015) Re: Gentile et al.: Microbiological spectrum and antibiotic sensitivity in endophthalmitis: a 25-year review (Ophthalmology 2014;121:1634-42). Ophthalmology 122(4):e23-24. 10.1016/j.ophtha.2014.08.050.

18. Deramo VA, Lai JC, Winokur J, Luchs J, Udell IJ. Visual outcome and bacterial sensitivity after methicillin-resistant Staphylococcus aureus-associated acute endophthalmitis. Am J Ophthalmol. 2008;145(3):413-7. 10.1016/j.ajo.2007.10.020.

19. Major JC Jr, Engelbert M, Flynn HW Jr, Miller D, Smiddy WE, Davis JL. Staphylococcus aureus endophthalmitis: antibiotic susceptibilities, methicillin resistance, and clinical outcomes. Am J Ophthalmol. 2010;149(2):278-83 e271. 10.1016/j.ajo.2009.08.023.

20. McDonald M, Blondeau JM. Emerging antibiotic resistance in ocular infections and the role of fluoroquinolones. J Cataract Refract Surg. 2010;36(9):1588-98. 10.1016/j.jcrs.2010.06.028.

21. Chiquet C, Maurin M, Altayrac J, Aptel F, Boisset S, Vandenesch F, Cornut PL, Romanet JP, Gain P, Carricajo A. (2015) Correlation between clinical data and antibiotic resistance in coagulase-negative Staphylococcus species isolated from 68 patients with acute post-cataract endophthalmitis. Clin Microbiol Infect 21(6):592 e591-598. 10.1016/j.cmi.2015.01.028.

22. Klonoff DC. (2019) The New FDA Real-World Evidence Program to Support Development of Drugs and Biologics. J Diabetes Sci Technol 1932296819832661. 10.1177/1932296819832661.

23. Lerche S, Liepelt-Scarfone I, Alves G, Barone P, Behnke S, Ben-Shlomo Y, Berendse H, Burn D, Dodel R, Grosset D, Heinzel S, Hu M, Kasten M, Kruger R, Maetzler W, Moccia M, Mollenhauer B, Oertel W, Roeben B, Sunkel U, Walter U, Wirdefeldt K, Berg D. Methods in Neuroepidemiology Characterization of European Longitudinal Cohort Studies in Parkinson's Disease-Report of the JPND Working Group. BioLoC-PD Neuroepidemiology. 2015;45(4):282-97. $10.1159 / 000439221$.

24. Jiang X, Deng A, Yang J, Bai H, Yang Z, Wu J, Lv H, Li X, Wen T. Pathogens in the Meibomian gland and conjunctival sac: microbiome of normal subjects and patients with Meibomian gland dysfunction. Infect Drug Resist. 2018;11:1729-40. 10.2147/IDR.S162135.

25. Kessel L, Flesner P, Andresen J, Erngaard D, Tendal B, Hjortdal J. Antibiotic prevention of postcataract endophthalmitis: a systematic review and metaanalysis. Acta Ophthalmol. 2015;93(4):303-17. 10.1111/aos.12684.

26. Taban M, Behrens A, Newcomb RL, Nobe MY, Saedi G, Sweet PM, McDonnell PJ. Acute endophthalmitis following cataract surgery: a systematic review of the literature. Arch Ophthalmol. 2005;123(5):613-20. 10.1001/archopht.123.5.613.

27. Kenchappa P, Sangwan VS, Ahmed N, Rao KR, Pathengay A, Mathai A, Mansoori T, Das T, Hasnain SE, Sharma S. (2005) High-resolution genotyping of Pseudomonas aeruginosa strains linked to acute post cataract surgery endophthalmitis outbreaks in India. Ann Clin Microbiol Antimicrob 4(19.

10.1186/1476-0711-4-19.

28. Pinna A, Usai D, Sechi LA, Zanetti S, Jesudasan NC, Thomas PA, Kaliamurthy J. (2009) An outbreak of post-cataract surgery endophthalmitis caused by Pseudomonas aeruginosa. Ophthalmology 116(12):2321-2326 e2321-2324. 10.1016/j.ophtha.2009.06.004.

29. Horster S, Bader L, Seybold U, Eschler I, Riedel KG, Bogner JR. Stenotrophomonas maltophilia induced post-cataract-surgery endophthalmitis: Outbreak investigation and clinical courses of 26 patients. Infection. 2009;37(2):117-22. 10.1007/s15010-008-8150-8.

30. Ding Y, Lin M, Liu H, Zhang W, Wang L, Li Y. Outcomes of post-cataract surgery endophthalmitis referred to a tertiary center from local hospitals in the south of China. Infection. 2011;39(5):451-60. 10.1007/s15010-011-0138-0.

31. Durand ML. Endophthalmitis Clin Microbiol Infect. 2013;19(3):227-34. 10.1111/1469-0691.12118.

32. Ji Y, Jiang C, Ji J, Luo Y, Jiang Y, Lu Y. (2015) Post-cataract endophthalmitis caused by multidrug-resistant Stenotrophomonas maltophilia: clinical features and risk factors. BMC Ophthalmol 15(14. 10.1186/1471-2415-15-14.

33. Lakshmi Priya J, Prajna L, Mohankumar V. Genotypic and phenotypic characterization of Pseudomonas aeruginosa isolates from post-cataract endophthalmitis patients. Microb Pathog. 2015;78:67-73. 10.1016/j.micpath.2014.11.014.

34. Slean GR, Shorstein NH, Liu L, Paschal JF, Winthrop KL, Herrinton LJ. Pathogens and antibiotic sensitivities in endophthalmitis. Clin Exp Ophthalmol. 2017;45(5):481-8. 10.1111/ceo.12910.

35. Rahmani S, Eliott D. Postoperative Endophthalmitis: A Review of Risk Factors, Prophylaxis, Incidence, Microbiology, Treatment, and Outcomes. Semin Ophthalmol. 2018;33(1):95-101. 10.1080/08820538.2017.1353826.

36. Silpa-Archa S, Papirachnart A, Singhanetr P, Preble JM. Risk factors for endophthalmitis after cataract surgery in diabetic patients: a case control study. Int J Ophthalmol. 2019;12(3):417-23. 10.18240/ijo.2019.03.11.

37. Egrilmez S, Yildirim-Theveny S. Treatment-Resistant Bacterial Keratitis: Challenges and Solutions. Clin Ophthalmol. 2020;14:287-97. 10.2147/OPTH.S181997.

38. Kleinschmidt S, Huygens F, Faoagali J, Rathnayake IU, Hafner LM. Staphylococcus epidermidis as a cause of bacteremia. Future Microbiol. 2015;10(11):1859-79. 10.2217/fmb.15.98.

39. Vuong C, Otto M. Staphylococcus epidermidis infections. Microbes Infect. 2002;4(4):481-9. 10.1016/s1286-4579(02)01563-0.

40. Kandi V, Palange P, Vaish R, Bhatti AB, Kale V, Kandi MR, Bhoomagiri MR. Emerging Bacterial Infection: Identification and Clinical Significance of Kocuria Species. Cureus. 2016;8(8):e731. 10.7759/cureus.731.

41. Lowy FD. Staphylococcus aureus infections. N Engl J Med. 1998;339(8):520-32. 10.1056/NEJM199808203390806.

42. Otto M. (2008) Staphylococcal biofilms. Curr Top Microbiol Immunol 322(207-228. 10.1007/978-3-540-75418-3\$410.

Page $14 / 17$ 
43. Cheung GY, Rigby K, Wang R, Queck SY, Braughton KR, Whitney AR, Teintze M, DeLeo FR, Otto M. Staphylococcus epidermidis strategies to avoid killing by human neutrophils. PLoS Pathog. 2010;6(10):e1001133. 10.1371/journal.ppat.1001133.

44. Loracher C, Dacian V, Rudolph W. [Left ventricular asynergy induced by beta receptor blockade in coronary heart disease]. Verh Dtsch Ges Kreislaufforsch. 1976;42:348-9.

45. Hedin G. Staphylococcus epidermidis-hospital epidemiology and the detection of methicillin resistance. Scand J Infect Dis Suppl. 1993;90:1-59.

46. Sipahi OR, Mermer S, Aydemir S, Ozgiray E, Cilli F, Oner K. Kocuria rosea meningitis. Surg Infect (Larchmt). 2014;15(5):659. 10.1089/sur.2013.220.

47. Ali MJ, Pujari A, Motukupally S, Naik MN. Kocuria rosea canaliculitis: a clinicomicrobiological correlation. Ophthalmic Plast Reconstr Surg. 2014;30(6):e139-40. 10.1097/IOP.0b013e3182a650dd.

48. Moreira JS, Riccetto AG, Silva MT, Vilela MM, Study Group Centro Medico de Campinas/Franceschi Medicina L. Endocarditis by Kocuria rosea in an immunocompetent child. Braz J Infect Dis. 2015;19(1):82-4. 10.1016/j.bjid.2014.09.007.

49. Ananieva MM, Faustova MO, Basarab IO, Loban GA. Kocuria rosea, kocuria kristinae, leuconostoc mesenteroides as caries-causing representatives of oral microflora. Wiad Lek. 2017;70(2 pt 2):296-8.

50. Gunaseelan P, Suresh G, Raghavan V, Varadarajan S. Native valve endocarditis caused by Kocuria rosea complicated by peripheral mycotic aneurysm in an elderly host. J Postgrad Med. 2017;63(2):135-7. 10.4103/jpgm.JPGM_441_16.

51. Srinivasa KH, Agrawal N, Agarwal A, Manjunath CN. (2013) Dancing vegetations: Kocuria rosea endocarditis. BMJ Case Rep 2013(10.1136/bcr-2013010339.

52. Lee MK, Choi SH, Ryu DW. (2013) Descending necrotizing Mediastinitis caused by Kocuria rosea: a case report. BMC Infect Dis 13(475. 10.1186/14712334-13-475.

53. Erbasan F. Brain abscess caused by Micrococcus luteus in a patient with systemic lupus erythematosus: case-based review. Rheumatol Int. 2018;38(12):2323-8. 10.1007/s00296-018-4182-2.

54. Seifert H, Kaltheuner M, Perdreau-Remington F. Micrococcus luteus endocarditis: case report and review of the literature. Zentralbl Bakteriol. 1995;282(4):431-5. 10.1016/s0934-8840(11)80715-2.

55. Martins EN, Alvarenga LS, Hofling-Lima AL, Freitas D, Zorat-Yu MC, Farah ME, Mannis MJ. Aerobic bacterial conjunctival flora in diabetic patients. Cornea. 2004;23(2):136-42. 10.1097/00003226-200403000-00006.

56. Fernandez-Rubio ME, Rebolledo-Lara L, Martinez-Garcia M, Alarcon-Tomas M, Cortes-Valdes C. The conjunctival bacterial pattern of diabetics undergoing cataract surgery. Eye (Lond). 2010;24(5):825-34. 10.1038/eye.2009.218.

57. Karimsab D, Razak SK. Study of aerobic bacterial conjunctival flora in patients with diabetes mellitus. Nepal J Ophthalmol. 2013;5(1):28-32. http://dx.doi.org/10.3126/nepjoph.v5i1.7818.

58. Mino De Kaspar H, Ta CN, Froehlich SJ, Schaller UC, Engelbert M, Klauss V, Kampik A. Prospective study of risk factors for conjunctival bacterial contamination in patients undergoing intraocular surgery. Eur J Ophthalmol. 2009;19(5):717-22. 10.1177/112067210901900505.

59. Jaruratanasirikul S, Jaspattananon A, Wongpoowarak W, Nawakitrangsan M, Thengyai S, Samaeng M. Population Pharmacokinetics and Pharmacodynamics Modeling of Oral Levofloxacin. J Med Assoc Thai. 2018;99(8):886-92.

60. Kim SJ, Moon DC, Park SC, Kang HY, Na SH, Lim SK. Antimicrobial resistance and genetic characterization of coagulase-negative staphylococci from bovine mastitis milk samples in Korea. J Dairy Sci. 2019. 10.3168/jds.2019-17028.

61. Fernandez Rubio E, Cuesta Rodriguez T, Cortes Valdes C. [Preoperative eye-drop antibiotherapy in cataract surgery]. Arch Soc Esp Oftalmol. 2004;79(5):213-9. 10.4321/s0365-66912004000500005.

62. Chojnacki M, Philbrick A, Wucher B, Reed JN, Tomaras A, Dunman PM, Wozniak RAF. (2019) Development of a Broad-Spectrum Antimicrobial Combination for the Treatment of Staphylococcus aureus and Pseudomonas aeruginosa Corneal Infections. Antimicrob Agents Chemother 63(1):10.1128/AAC.01929-18.

63. Daien V, Papinaud L, Gillies MC, Domerg C, Nagot N, Lacombe S, Daures JP, Carriere I, Villain M. Effectiveness and Safety of an Intracameral Injection of Cefuroxime for the Prevention of Endophthalmitis After Cataract Surgery With or Without Perioperative Capsular Rupture. JAMA Ophthalmol. 2016;134(7):810-6. 10.1001/jamaophthalmol.2016.1351.

64. Herrinton LJ, Shorstein NH, Paschal JF, Liu L, Contreras R, Winthrop KL, Chang WJ, Melles RB, Fong DS. Comparative Effectiveness of Antibiotic Prophylaxis in Cataract Surgery. Ophthalmology. 2016;123(2):287-94. 10.1016/j.ophtha.2015.08.039.

65. Rudnisky CJ, Wan D, Weis E. Antibiotic choice for the prophylaxis of post-cataract extraction endophthalmitis. Ophthalmology. 2014;121(4):835-41. 10.1016/j.ophtha.2013.08.046.

66. Carron A, Samudio M, Laspina F, Farina N, Sanabria RR, Cibils D, Ramirez L, Carron J, Mino de Kaspar H. [Efficacy of topical 0.3\% ciprofloxacin application in reducing the conjunctival biota of patients undergoing cataract extraction]. Arch Soc Esp Oftalmol. 2013;88(9):345-51. 10.1016/j.oftal.2013.01.001.

67. Friling E, Lundstrom M, Stenevi U, Montan P. Six-year incidence of endophthalmitis after cataract surgery: Swedish national study. J Cataract Refract Surg. 2013;39(1):15-21. 10.1016/j.jcrs.2012.10.037.

68. Vaninbroukx I, Van Calster J, Van Calster B, Spileers W, Verhaegen J, Stalmans P. Preoperative eye disinfection in vitrectomy surgery using antibiotic or antiseptic eyedrops. Bull Soc Belge Ophtalmol. 2010;315:9-12.

69. He L, Ta CN, Hu N, Sinnar S, Mino de Kaspar H. Prospective randomized comparison of 1-day and 3-day application of topical 0.5\% moxifloxacin in eliminating preoperative conjunctival bacteria. J Ocul Pharmacol Ther. 2009;25(4):373-8. 10.1089/jop.2008.0102.

70. Vasavada AR, Gajjar D, Raj SM, Vasavada V, Vasavada V. Comparison of 2 moxifloxacin regimens for preoperative prophylaxis: prospective randomized triple-masked trial. Part 2: residual conjunctival flora. J Cataract Refract Surg. 2008;34(8):1383-8. 10.1016/j.jcrs.2008.05.018.

Page 15/17 
71. Bucci FA Jr, Amico LM, Evans RE. Antimicrobial efficacy of prophylactic gatifloxacin $0.3 \%$ and moxifloxacin $0.5 \%$ in patients undergoing phacoemulsification surgery. Eye Contact Lens. 2008;34(1):39-42. 10.1097/ICL.0b013e3180645d01.

72. Aslan O, Teberik K, Yucel M, Gur N, Karakoc AE. Effect of topical netilmicin on the reduction of bacterial flora on the human conjunctiva. Eur J Ophthalmol. 2008;18(4):512-6. 10.1177/112067210801800402.

73. Moss JM, Nguyen D, Liu YI, Singh K, Montague A, Egbert PR, Kaspar HM, Ta CN. Comparison of one-day versus one-hour application of topical gatifloxacin in eliminating conjunctival bacterial flora. Ophthalmology. 2008;115(11):2013-6. 10.1016/j.ophtha.2008.06.024.

74. Eggers M. Infectious Disease Management and Control with Povidone lodine. Infect Dis Ther. 2019. 10.1007/s40121-019-00260-x.

75. Fan F, Zhao Z, Zhao X, Ma Q, Li K, Fu W, Jia Z. Reduction of Ocular Surface Damage and Bacterial Survival Using 0.05\% Povidone-lodine Ocular Surface Irrigation before Cataract Surgery. Ophthalmic Res. 2019;62(3):166-72. 10.1159/000501373.

76. Wass S, Albrektsen G, Odegard MT, Sand M, Austeng D. Antiseptic effect of low-concentration povidone-iodine applied with a depot device in the conjunctiva before cataract surgery. Eye (Lond). 2018;32(12):1900-7. 10.1038/s41433-018-0198-9.

77. Nguyen CL, Oh LJ, Wong E, Francis IC. Povidone-iodine 3-minute exposure time is viable in preparation for cataract surgery. Eur J Ophthalmol. 2017;27(5):573-6. 10.5301/ejo.5000964.

78. Matsuura K, Miyazaki D, Sasaki SI, Yakura K, Inoue Y, Sakamoto M. Effectiveness of timely intraoperative iodine irrigation during cataract surgery. Jpn J Ophthalmol. 2016;60(6):433-8. 10.1007/s10384-016-0471-z.

79. Hsu J, Gerstenblith AT, Garg SJ, Vander JF. Conjunctival flora antibiotic resistance patterns after serial intravitreal injections without postinjection topical antibiotics. Am J Ophthalmol. 2014;157(3):514-8 e511. 10.1016/j.ajo.2013.10.003.

80. Li B, Nentwich MM, Hoffmann LE, Haritoglou C, Kook D, Kampik A, Sheng M, Mino de Kaspar H. Comparison of the efficacy of povidone-iodine 1.0\%, 5.0\%, and $10.0 \%$ irrigation combined with topical levofloxacin $0.3 \%$ as preoperative prophylaxis in cataract surgery. J Cataract Refract Surg. 2013;39(7):9941001. 10.1016/j.jcrs.2013.02.039.

81. Nentwich MM, Rajab M, Ta CN, He L, Grueterich M, Haritoglou C, Gandorfer A, Kampik A, Mino De Kaspar H. Application of $10 \%$ povidone iodine reduces conjunctival bacterial contamination rate in patients undergoing cataract surgery. Eur J Ophthalmol. 2012;22(4):541-6. 10.5301/ejo.5000093.

82. Coskun M, Altintas AG, Anayol MA, Raza S, Celikbilek N, Simsek S. Evaluation of efficacy of topical povidone-iodine and different types of fluoroquinolones in the sterilization of bacterial flora on the conjunctiva. J Ocul Pharmacol Ther. 2011;27(6):589-92. 10.1089/jop.2010.0192.

83. Quiroga LP, Lansingh V, Laspina F, Samudio M, Stanley J, Kaspar HM, Cibils D, Cibils P. A prospective study demonstrating the effect of 5\% povidoneiodine application for anterior segment intraocular surgery in Paraguay. Arq Bras Oftalmol. 2010;73(2):125-8. 10.1590/s0004-27492010000200005.

84. Carrim ZI, Mackie G, Gallacher G, Wykes WN. The efficacy of 5\% povidone-iodine for 3 minutes prior to cataract surgery. Eur J Ophthalmol. 2009;19(4):560-4. 10.1177/112067210901900407.

85. Halachmi-Eyal O, Lang Y, Keness Y, Miron D. Preoperative topical moxifloxacin $0.5 \%$ and povidone-iodine $5.0 \%$ versus povidone-iodine $5.0 \%$ alone to reduce bacterial colonization in the conjunctival sac. J Cataract Refract Surg. 2009;35(12):2109-14. 10.1016/j.jcrs.2009.06.038.

86. Mino de Kaspar H, Kreutzer TC, Aguirre-Romo I, Ta CN, Dudichum J, Bayrhof M, Klauss V, Kampik A. A prospective randomized study to determine the efficacy of preoperative topical levofloxacin in reducing conjunctival bacterial flora. Am J Ophthalmol. 2008;145(1):136-42. 10.1016/j.ajo.2007.08.031.

\section{Figures}

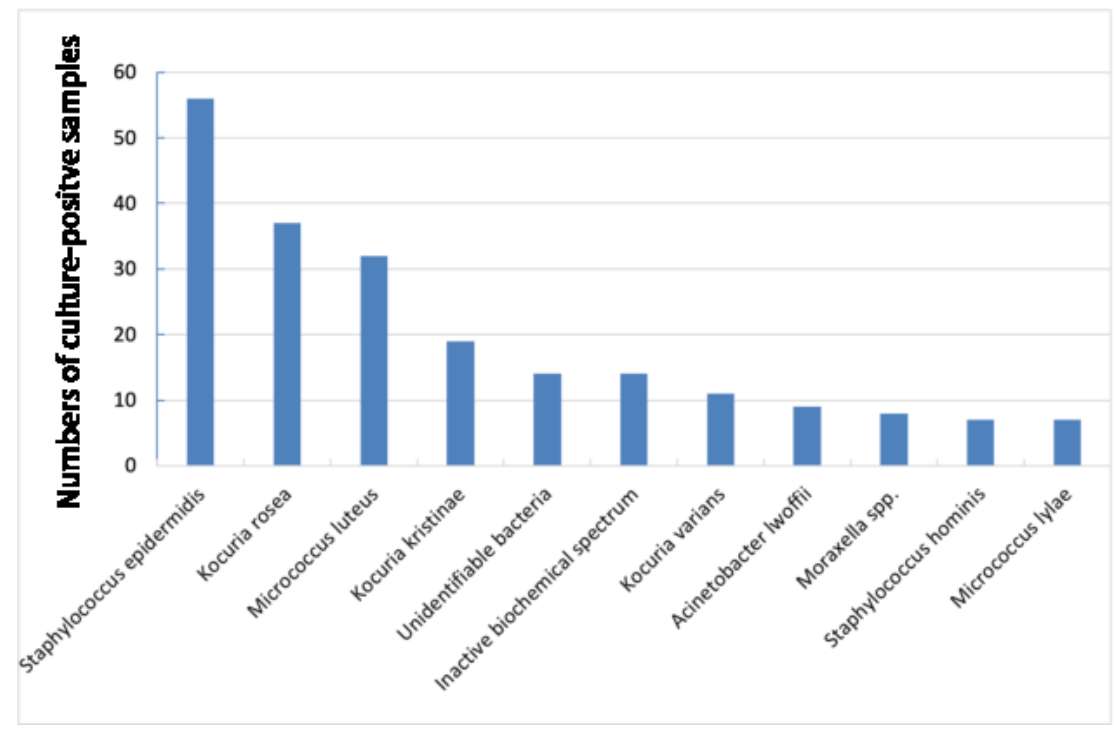

\section{Figure 1}

Number of culture-positive samples for the top 10 identified bacterial strains. 


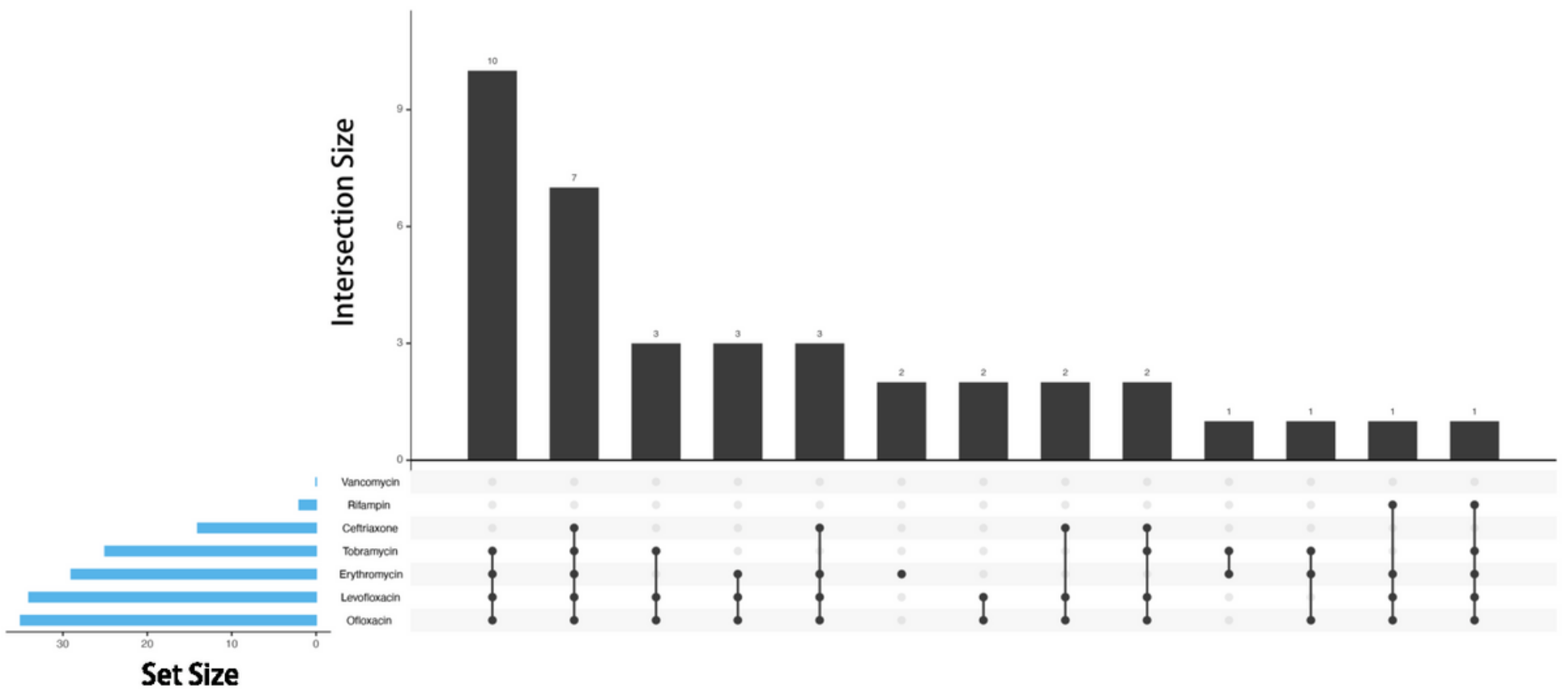

Figure 2

Upsetview of multidrug resistance of Staphylococcus epidermidis.

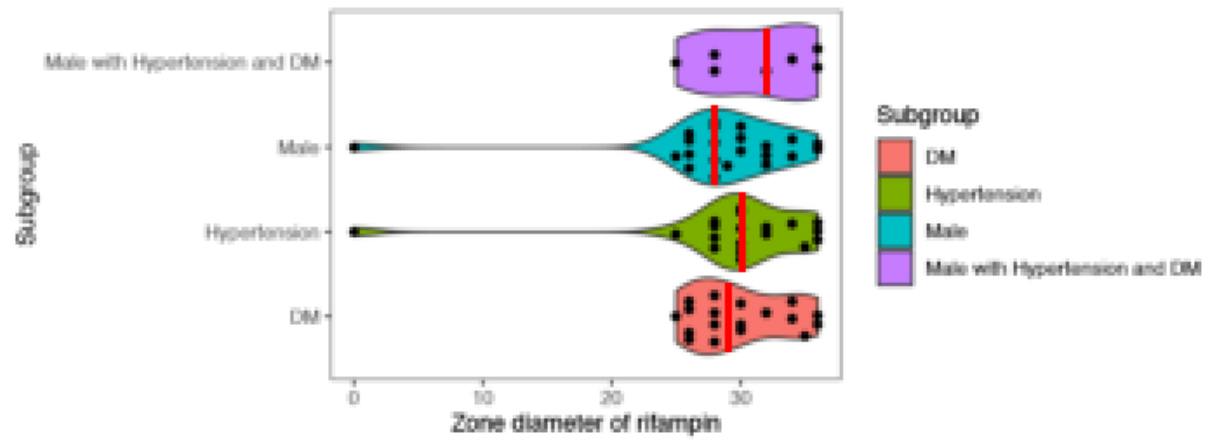

Figure 3

Violin plot of K-B test of Staphylococcus epidermidis against Rifampin. Each red line represents the median of each subgroup.

\section{Supplementary Files}

This is a list of supplementary files associated with this preprint. Click to download.

- authorship.pdf 